\title{
Charitable Contributions and the Personal Income Tax: Evaluating the Canadian Credit
}

\author{
David G. Duff*
}

\section{Introduction}

The last fifteen years have witnessed significant changes in the way that charitable contributions by individuals are treated under the Canadian Income Tax Act. ${ }^{1}$ In 1984, an optional standard deduction of $\$ 100$, which taxpayers could claim irrespective of the amount actually contributed to charities, was repealed. $^{2}$ In the same year, rules governing the taxation year in which charitable contributions could be deducted were relaxed, permitting taxpayers to claim amounts up to five years after the year of the gift. ${ }^{3}$ More recently, amendments have increased the maximum limit on charitable gifts eligible for tax assistance from 20 percent of the taxpayer's annual income to 50 percent for 1996 and 75 percent for 1997 and subsequent taxation years, ${ }^{4}$ and reduced the taxable amount of any gain on charitable gifts of certain publicly-traded securities made after February 18, 1997 and before 2002 from three-quarters of the gain to three-eighths. ${ }^{5}$

\footnotetext{
*Assistant Professor, Faculty of Law, University of Toronto. I am indebted to Elizabeth Moore for research assistance in the preparation of this paper. I am also indebted to Bruce Chapman and Lisa Philipps for helpful comments on an earlier draft.

${ }^{1}$ R.S.C. 1985, c.1 (5th Supp.) [as amended] (hereinafter the "Act").

${ }^{2}$ S.C. 1984, c. 1, subsec. 49(2), repealing former paragraph $110(1)(d)$ of the Act. At the time of its abolition, this deduction, which was established in 1957, applied to charitable donations and medical expenses. Although it originally included union, professional or other dues as well, these items were excluded from the standard deduction in 1965. On the history and rationale of this optional standard deduction, see infra, Part II, Section 3.

${ }^{3}$ S.C. 1985 , c. 45 , subsec. 54(1), amending former paragraphs 110(1)(a), (b) and (b.1) of the Act. Prior to 1984, individuals could deduct amounts up to five years after the year of the gift only where their net income was insufficient to exhaust the deduction. Before 1981, the carryforward was limited to the taxation year immediately following the year of the gift. On the history and structure of these carryovers, see infra, Part II, Section 7.

${ }^{4}$ See S.C. 1997, c. 25, s. 26 (increasing the limit to 50 percent), and S.C. 1998, c. 19, subsec. 22(14) (increasing the limit to 75 percent). These limits are found in the definition of "total gifts" in subsection 118.1(1)of the Act. The limit is increased by the 25 percent of any taxable capital gain or recaptured depreciation resulting from a gift of appreciated property for which tax relief is claimed, and increased to 100 percent for the taxation year of the donor's death and the subsequent taxation year. These limits do not apply with respect to qualifying gifts of cultural property designated under the Cultural Property Export and Import Act ("total cultural gifts"), gifts of ecologically sensitive land ("total ecoligical gifts"), or gifts to the Crown ("total Crown gifts"). On the history and structure of these ceilings, see infra, Part II, Section 6.

${ }^{5}$ See paragraph 38(a.1) of the Act, added by S.C. 1998, c. 19, s. 6. On the history and rationale for this provision, see infra, Part II, Section 4.
} 
The most significant change, however, involves the conversion in 1988 of what had previously been a deduction for charitable contributions whereby the value of the tax benefit depends on the donor's level of income, ${ }^{6}$ into a tax credit under which the value of this benefit depends on the total amount of charitable contributions claimed in the particular taxation year. ${ }^{7}$ As a result of this amendment, Canada has become the only developed country that recognizes charitable contributions by individuals in the form of a tax credit rather than a deduction. ${ }^{8}$

This paper evaluates the merits of this policy change and the structure of the Canadian charitable contributions tax credit in light of alternative possible rationales for the recognition of these gifts in computing the amount of tax payable under an income tax. Part II reviews the history of Canadian income tax provisions regarding charitable contributions by individuals and explains the structure of the current tax credit and related provisions governing the tax treatment of charitable contributions by individuals. Part III examines alternative rationales and related tax designs for the recognition of these charitable gifts in computing the amount of tax payable under an income tax, rejecting the views that recognition is necessary to define income or reward altruism, but accepting the arguments that tax assistance may have a useful role to play to promote pluralism by encouraging donations. Part IV offers brief conclusions on the current Canadian tax credit in light of the rationales and design characteristics examined in Part III.

\section{History and Structure}

Although the Canadian income tax currently recognizes charitable contributions in the form of a credit against basic tax otherwise payable, not a deduction in computing taxable income, the basic structure of the credit and other provisions relating to charitable contributions dates back to 1930 when the Income War Tax $A c t^{9}$ was amended by the addition of a deduction for charitable donations. ${ }^{10}$ This part examines the history of tax relief for charitable contributions in order to explain the current scheme of the Act.

\footnotetext{
${ }^{6}$ See former paragraphs 110(1)(a), (b) and (b.1) of the Act, repealed by S.C. 1988, c. 55, s. 92 . As explained at infra, Part II, Section 5, the value of a deduction under an income tax with graduated or progressive rates, is worth more to a high-income taxpayer paying tax at a higher marginal rate than to a low-income taxpayer who is taxable at a lower marginal rate.

${ }^{7}$ See subsection 118.1(3) of the Act (added by S.C. 1988, c. 55, s. 92), which provides for a credit against tax otherwise payable equal to $17 \%$ of the first $\$ 200$ of total gifts for the year and $29 \%$ of amounts exceeding \$200. To the extent that the credit is not refundable and therefore of no value to donors whose income is such that they pay no tax, its value may also depend on the donor's level of income.

${ }^{8}$ See Sheila Avrin McLean, Rona Kluger and Robert Henrey, Charitable Contributions in the OECD: A Tax Study, (Alexandria, VA: Interphil, 1990). While some countries (e.g., Sweden) provide no tax recognition for charitable contributions by individuals, most countries (e.g., France, Germany, Japan and the United States) provide a deduction in computing the donor's income for the taxation year in which the contribution was made or certain other taxation years. In Spain, tax credits are available for a limited category of donations of heritage property to the Spanish Government, other public entities or qualified recipients.

${ }^{9}$ S.C. 1917 , c. 28.

${ }^{10}$ See paragraph 5(1)(j) of the Income War Tax Act, S.C. 1917, c. 28, as amended by S.C. 1930, c. 24, s. 3.
} 


\section{Deduction}

When Canada adopted its first income tax in 1917, the Act contained a limited deduction for "amounts paid by the taxpayer during the year to the Patriotic and Canadian Red Cross Funds, and other patriotic and war funds approved by the Minister". ${ }^{11}$ While this provision was repealed in $1920{ }^{12}$ a more general deduction was adopted in 1930, at which time a provision was introduced allowing taxpayers to deduct:

... not more than ten per centum of the net taxable income of any taxpayer which has been actually paid by way of donation within the taxation period to, and receipted for as such by, any charitable organization in Canada operated exclusively as such and not operated for the benefit or private gain or profit of any person, member or shareholder thereof. ${ }^{13}$

Based on this provision, therefore, taxpayers could deduct receipted donations to qualifying "charitable organizations" up to an annual maximum of 10 percent of their net taxable income, computed after deducting various costs of earning income and other personal amounts such as medical expenses and allowances for dependants. While subsequent amendments imposed a registration requirement on charitable organizations, ${ }^{14}$ and increased the annual ceiling on deductible contributions to 20 percent, ${ }^{15}$ the deduction itself was little changed until its conversion to a tax credit in $1988 .^{16}$ Indeed, the credit itself continues to contain a income-related ceiling on extent to which charitable contributions qualify for the credit. $^{17}$

Notwithstanding six pages of Parliamentary debate, most of which centered on the kinds of organizations donations to which would qualify for the deduction, ${ }^{18}$ there was remarkably little discussion of the purpose for which the deduction was introduced. ${ }^{19}$ Referring to comments by then Leader of the Opposition R.B. Bennett, however, one commentator concludes that "it was thought that the deduction

\footnotetext{
${ }^{11}$ Income War Tax Act, S.C. 1917, c. 28, paragraph 3(1)(c).

${ }^{12}$ S.C. 1920 , c. 49 , s. 5 .

${ }^{13}$ Income War Tax Act, S.C. 1917, c. 28, paragraph 5(1)(j), as amended by S.C. 1930, c. 24 , s. 3.

${ }^{14}$ S.C. $1966-67$, c. 47, s. 3(1), amending then paragraph 27(1)(a) of the 1952 Income Tax Act, R.S.C. 1952 , c. 148.

${ }^{15}$ See former paragraph 110(1)(a) of the Act, enacted by S.C. 1970-71-72, c. 63, s.1. The evolution of this ceiling is examined more fully at infra, Part II, Section 6.

${ }^{16}$ See subsection 118.1(3) of the Act, added by S.C. 1988, c. 55, s. 92.

${ }^{17}$ See paragraph (a) of the definition of "total gifts" in subsection 118.1(1) of the Act. This ceiling is examined at infra, Part II, Section 6.

${ }^{18}$ See Rod Watson, "Charity and the Canadian Income Tax Act: An Erratic History" (Spring 1985), 5 The Philanthropist 3 at 8-9. Although the initial amendment proposed that the deduction be available only for donations to "any church, university, college, school or hospital in Canada", the more general words "charitable organization" were substituted after concern was expressed that contributions to many worthy causes, such as the Red Cross and community funds such as the Federated Charities of Montreal would not qualify.

${ }^{19}$ R.M. Bird and M.W. Bucovetsky, Canadian Tax Reform and Private Philanthropy, Tax Paper No. 58, (Toronto: Canadian Tax Foundation, 1976) at 17.
} 
would encourage wealthy taxpayers to contribute to 'useful, philanthropic and religious purposes' and that such contributions were laudable and deserving of encouragement in this fashion.,"20

In the United States, where a similar deduction was adopted in $1917{ }^{21}$ four years after the introduction of its income tax in 1913, the deduction was designed to offset any discouragement to charitable contributions that might be caused by high tax rates needed to finance American participation in the First World War. ${ }^{22}$ Similarly, as the Royal Commission on Dominion-Provincial Relations observed in 1940, the Canadian deduction was intended "to promote munificence or at least to protect charities against the indirect consequence of high rates of income tax on those who sustain them. ${ }^{23}$

More generally, the Canadian deduction, which was enacted in the early years of the Great Depression at a time when governments were increasingly pressed to provide relief to the unemployed, was a method whereby the federal government could "be seen to be assisting those in need" without itself assuming responsibility for relief or becoming involved in what was at the time a sphere of exclusive provincial jurisdiction. ${ }^{24}$ In this respect, as another commentator has observed, the Canadian deduction was introduced in order to promote "public policy and the general good of the community.,"25

\section{Qualifying Gifts}

Among the early questions considered by Canadian courts in applying the deduction was whether it applied to gifts in kind as well as cash donations. In Gaudin v. M.N.R., ${ }^{26}$ where the taxpayer sold a house to a church for use as a rectory for half its value and claimed the other half as a charitable deduction, the court held that the contribution was not a "gift" within the meaning of then paragraph 27(1)(a) of the 1952 Income Tax Act. ${ }^{27}$ Although the decision appeared to suggest that gifts-in-kind were not deductible, ${ }^{28}$ a subsequent decision, in which a taxpayer was permitted to claim a deduction in respect of the value of a yacht donated to the University of Toronto confirmed that the deduction applied to gifts in

\footnotetext{
${ }^{20}$ James A. Rendall, "Taxation of Contributors to Charitable Organizations Under the Income Tax Act," in Report of the Proceedings of the Twenty-Fifth Tax Conference, 1973 Conference Report, (Toronto: Canadian Tax Foundation, 1974) 152 at 153.

${ }^{21}$ Revenue Act of 1917, Ch. 73, s. 1201(2), 40 Stat. 300, 330, permitting a deduction for: "Contributions or gifts actually made within the year to corporations or associations organized and operated exclusively for religious, charitable, scientific or educational purposes, or to societies for the prevention of cruelty to children or animals, no part of the net income of which insures to the benefit of any private stockholder or individual, to an amount not in excess of fifteen per centum of the taxpayer's taxable net income as computed without the benefit of this paragraph."

${ }^{22}$ See Richard Goode, The Individual Income Tax, Revised Edition (Washington, D.C.: The Brookings Institution, 1976) at 160.

${ }^{23}$ Report of the Royal Commission on Dominion-Provincial Relations (Ottawa, 1940), Vol. II at 161.

${ }^{24}$ Watson, supra note 18 at 9.

${ }^{25}$ Gwyneth McGregor, "Charitable Contributions" (1961), 9 Can. Tax J. 441 at 448

${ }^{26} 55$ D.T.C. 385 (T.A.B.).

${ }^{27}$ R.S.C. 1952 , c. 148.

${ }^{28}$ See Rendall, supra note 20 at 155.
} 
kind. ${ }^{29}$ This result is now reflected in the language of subsection 118.1(1) which refers to "the fair market value" of gifts of various kinds. ${ }^{30}$ As an administrative practice, however, Revenue Canada does not recognize gifts-in-kind of nominal value, such as gifts of used clothing of little value. ${ }^{31}$ As well, gifts of services are not recognized as charitable contributions within the meaning of the Act. ${ }^{32}$

Among tax theorists, non-recognition of gifts of services as charitable contributions is often explained on the basis that the donor obtains an implicit deduction through the non-taxation of the "imputed income" associated with the gift of services. ${ }^{33}$ Indeed, to the extent that a person who contributes services is not subject to tax on the value of these services, while a person who works to earn the income to make a cash contribution is subject to tax on the earnings, it is often argued that a deduction for cash donations is essential to achieve equity between these two taxpayers. ${ }^{34}$ More persuasively, it might be argued that non-recognition of the value of gifts of services is consistent with non-taxation of imputed income from self-performed services. ${ }^{35}$ On the other hand, to the extent that tax assistance is designed to encourage charitable gifts and subsidize charitable activities, there seems little reason limit this incentive to gifts of cash and property while excluding gifts of services. ${ }^{36}$

\section{Optional Standard Deduction}

\footnotetext{
${ }^{29}$ Consolidated Truck Lines v. M.N.R., [1968] Tax A.B.C. 472, 68 D.T.C. 399.

${ }^{30}$ See also Interpretation Bulletin IT-297R2 "Gifts in Kind to Charity and Others" (March 21, 1990).

${ }^{31}$ Ibid. at para. 6.

${ }^{32}$ See Slobodrian v. The Queen, [1998] 3 C.T.C. 2654 (T.C.C.), rejecting the taxpayer's claim for a charitable contributions credit in respect of unpaid labour performed for the University of Laval on the grounds that a "gift" involves the transfer of property and services are not property. See also Interpretation Bulletin IT-110R3, "Gifts and Official Donation Receipts" (July 20, 1997) at para. 15(d), stating that: "A gift must involve property. Contributions of services (that is, time, skills, effort) are not property and do not qualify." Since the Act refers only to "the fair market value of a gift" not "the fair market value of a gift of property", it is questionable whether this result is mandated by the words of the statute.

${ }^{33}$ See, e.g., Goode, supra note 22 at 166.

${ }^{34}$ See, e.g., Boris I. Bittker, "The Propriety and Vitality of a Federal Income Tax Deduction for Private Philanthropy," in Tax Impacts on Philanthropy, Symposium conducted by the Tax Institute of America (Princeton: Tax Institute of America, 1972) 145 at 166; and William Andrews, "Personal Deductions in an Ideal Income Tax" (1972), 86 Harv. L. Rev. 309 at 347-48. I return to this issue at infra, Part III, Section 1 .

${ }^{35}$ The arguments against the taxation of imputed income are both ethical and administrative. First and foremost, to the extent that an income tax applies and should apply to market activities, it is inappropriate to subject non-market activities to tax. Moreover, since non-market activities are extremely difficult to value in any objective manner, it is difficult in practice to include such activities in an income tax. For an excellent presentation of the argument against taxing imputed income, see Thomas Chancellor, "Imputed Income and the Ideal Income Tax" (1988), 67 Oregon L. Rev. 561. For a persuasive response to the argument that a deduction for charitable contributions is necessary to equalize the position of taxpayers who contribute cash and those who contribute services, see Mark G. Kelman, "Personal Deductions Revisited: Why They Fit Poorly in an 'Ideal' Income Tax and Why They Fit Worse in a Far from Ideal World" (1979), 31 Stan. L. Rev. 831 at 838-44. I return to this issue at infra, Part III, Section 1.

${ }^{36}$ See, e.g., Paul R. McDaniel, "Federal Matching Grants for Charitable Deductions: A Substitute for the Income Tax Deduction" (1972), 27 Tax Law Rev. 377 at 396, suggesting that "federal assistance could match contributions in services just as it could contributions in cash" if it is desired "to encourage volunteer work".
} 
The first significant amendment to the charitable deduction involved the enactment of an optional standard deduction in 1957 , whereby taxpayers could claim a $\$ 100$ deduction without submitting receipts in lieu of specific deductions for charitable contributions, medical expenses medical expenses (which were deductible only to the extent that they exceeded 3 percent of the taxpayer's net income ${ }^{37}$ ), and union, professional or similar dues. ${ }^{38}$ The reason for this standard deduction, which had been adopted in the United States in $1944,{ }^{39}$ was to limit paperwork both for the revenue authorities and for taxpayers. According to the Minister of Finance:

From a survey it has been established that for more than half of income taxpayers the combined claims for charitable contributions, medical expenses, union dues and professional fees of employees amount to less than $\$ 100$ a year per taxpayer. In the light of this situation it is proposed to allow to every taxpayer the option of taking what might be called a "standard deduction" of $\$ 100$ a year in lieu of claiming actual deductions for the items just mentioned. Of course if the claims for these four items add up to more than $\$ 100$ the taxpayer may obtain a deduction in the future just as he has in the past. For the majority of taxpayers, however, the standard deduction will prove more advantageous and will, for all concerned, eliminate handling million of pieces of paper. ${ }^{40}$

While the optional standard deduction certainly reduced paperwork, ${ }^{41}$ it also eliminated any tax incentive to make contributions to charities that, together with qualifying medical expenses and union, professional or similar dues did not exceed $\$ 100$ per year -- since this amount could be claimed in any event without submitting receipts. Indeed, although the effect of the optional standard deduction on amounts actually contributed to charities is uncertain, the percentage of taxfilers claiming charitable deductions decreased dramatically after 1956. According to one study published in 1976, total charitable donations of $\$ 284$ million claimed in 1956, the year before the optional standard deduction was introduced, exceeded the total of itemized deductions for charitable contributions in each of the years 1966 to $1971 .^{42}$ According to another study published in 1984, after increasing from 1951 to 1956 , average amounts claimed as charitable donations as a percentage of average disposable personal income declined steadily from 1.9 percent in 1956 to 0.54 percent in 1974 before rising slightly to 0.61 percent in $1980{ }^{43}$

\footnotetext{
${ }^{37}$ Although this medical expense deduction, like the charitable contributions deduction, was converted to a credit in 1988, it continues to apply only above a minimum amount which is currently the lesser of $\$ 1,500$ [inflation adjusted after 1988] and 3 percent of the taxpayer's income for the year. See subsection 118.2(1) of the Act.

${ }^{38}$ See paragraph 27(1)(ca) of the 1952 Income Tax Act, added by S.C. 1957, c. 29, s. 7(3). In 1972, this provision became former paragraph 110(1)(d) of the Act.

${ }^{39}$ Marvin Chirelstein, Federal Income Taxation, 5th edn., (Westbury, N.Y.: The Foundation Press, 1988) at 157.

${ }^{40}$ Hon. Walter Harris, Minister of Finance, Budget Speech, (March 14, 1957) at 13.

${ }^{41}$ According to McGregor, supra note 25 at 449,62 percent of returns filed by taxable individuals claimed the standard deduction the year after it was enacted. By 1980, the percentage of taxfilers claiming the standard deduction had increased to 88.7 percent. Calculated from Revenue Canada, on Individuals: 1980 Tax Year, (Ottawa: Minister of Supply and Services, 1982).

${ }^{42}$ Bird and Bukovetsky, supra note 19 at 8 .

${ }^{43}$ J.F. Deeg, "How and What Canadians Contribute to Charity," (Winter 1984) The Philanthropist 3 at 11 (Table I).
} 
Similarly, the percentage of taxfilers claiming charitable donations decreased from 24.5 percent in 1961 to 9.2 percent in 1977 before recovering slightly to 10.3 percent in $1980 .^{44}$

Although it is unlikely that these declines were fully attributable to the optional standard deduction, which might have been expected to have its largest effects immediately after its enactment in 1956 and again in 1965 when the deduction was amended to exclude union, professional or similar dues, ${ }^{45}$ and a diminishing impact thereafter as the real value of the $\$ 100$ deduction was eroded by inflation, ${ }^{46}$ the measure was sharply criticized by advocates for voluntary organizations on the grounds that it lessened tax incentives to contribute to charities. ${ }^{47}$ When the Royal Commission on Taxation (Carter Commission) delivered its final report in 1966, it accepted the optional standard deduction as "an administrative concession" but recommended that its dollar value be reduced. ${ }^{48}$ According to the Commission:

... if an optional standard deduction, that is, a minimum amount that could be claimed instead of listing the actual donations and irrespective of the amount of actual donations, were too large, ... it would ... have a perverse incentive effect, discouraging those people from making moderate donations who could claim the standard deduction in any case. For this reason, we recommend that an optional standard deduction should be retained for charitable donations, but that it should be limited in size to the minimum amount necessary to achieve the desired administrative savings. ${ }^{49}$

For this purpose, it recommended, "[a]n amount of not more than $\$ 50$ would appear to be appropriate., $" 50$

Although the federal government did not act on the Carter Commission's recommendation when it amended the Income Tax Act in 1972, the optional standard deduction was eventually repealed effective for 1984 and subsequent taxation years. ${ }^{51}$ According to documents released with the 1983 Federal Budget:

Representatives of voluntary associations have expressed concern that this deduction reduces the tax incentive for charitable giving since the deduction is not directly related to actual amounts

\footnotetext{
${ }^{44}$ Ibid. at 11 (Table II).

${ }^{45}$ S.C. 1965 , c. 18 , s. $7(1)$, repealing then subparagraph $27(1)(\mathrm{ca})(\mathrm{i})$.

${ }^{46}$ Other more persuasive explanations for a long-term decline in the frequency and amount of charitable donations include an increasing proportion of younger taxpayers, rising personal incomes, and reductions in top marginal tax rates in 1972 and 1977, which increased the after-tax cost of making charitable donations. To the extent that charitable contributions are positively correlated with age, increase less rapidly than increases in personal disposable income, and are negatively correlated with the cost of giving, these developments are likely to have been as significant, or more so, than the optional standard deduction. For a brief summary of empirical studies on the impact of age, income and the cost of giving on charitable contributions see Kimberley Scharf, Ben Cherniavsky and Roy Hogg, Tax Incentives for Charities in Canada, Working Paper No. CPRN 03, (Ottawa: Canadian Policy Research Networks, 1997) at 11-17.

${ }^{47}$ See, e.g., Novia Carter, Trends in Voluntary Support for Nongovernment Social Service Agencies (Ottawa: Canadian Council on Social Development, 1974) at 87.

${ }^{48}$ Report of the Royal Commission on Taxation, Vol. 3, (Ottawa: Queen's Printer, 1966) at 224 [hereinafter Carter Commission]. As an alternative to the optional standard deduction, the Commission considered limiting the deduction to amounts exceeding 1 percent of the donor's income. This approach was rejected, however, on the basis that "a limit of this nature might tend to restrain charitable giving by upper income taxpayers that the allowance is designed to encourage." Ibid.

${ }^{49}$ Ibid.

${ }^{50} \mathrm{Ibid}$.

${ }^{51}$ S.C. 1984, c. 1, subsec. 49(2), repealing former paragraph 110(1)(d) of the Act.
} 
given. The budget proposal to remove the $\$ 100$ standard deduction for 1984 and subsequent taxation years responds to this concern. ${ }^{52}$

Not surprisingly, the percentage of taxfilers claiming charitable contributions increased substantially following this amendment, rising from 10.3 percent in 1980 to 25.7 percent in $1984 .^{53}$ Since, then, however, the incidence of taxfilers claiming charitable contributions has remained relatively constant, rising to 29.5 percent in 1990 and declining thereafter to 26.9 percent in $1996 .{ }^{54}$ As for dollar amounts, aggregate amounts claimed as charitable donations increased from slightly more than $\$ 1$ billion in 1980 to more than $\$ 1.8$ billion in $1984 .^{55}$ Since the aggregate amount claimed under the optional standard deduction was roughly $\$ 1.3$ billion in $1980,{ }^{56}$ however, the information provided by this latter statistic is of limited value. More generally, whether the elimination of the optional standard deduction has had any impact on actual charitable contributions, as opposed to charitable contributions claimed for tax purposes, is uncertain.

\section{Gifts of Appreciated Property}

Among the many amendments to the Income Tax Act following the Report of the Royal Commission on Taxation (Carter Commission), perhaps the most significant was the introduction of a tax on capital gains, one-half of which became subject to tax beginning in $1972 .{ }^{57}$ This inclusion rate was increased to two-thirds in 1988 and 1989 and three-quarters for 1990 and subsequent taxation years. ${ }^{58}$ In addition to this measure, the federal government adopted the Carter Commission's recommendation to impose a tax on accrued gains when property it transferred by way of gift or at death ${ }^{59}$ by enacting provisions deeming the donor to have received proceeds equal to the fair market value of the property so transferred. ${ }^{60}$ As a result, while taxpayers making a charitable donation of capital property that had appreciated in value would be able to deduct the appreciated value of the property at the time the gift, they would also have to include half the amount of any accrued gain in computing their income in the year of the gift. ${ }^{61}$ Thus, for example, if a taxpayer acquired a capital asset for $\$ 1,000$ and gave it to a charity when its value had risen to $\$ 5,000$, the taxpayer would be able to claim a deduction for $\$ 5,000$ (subject to the

\footnotetext{
${ }^{52}$ Department of Finance, Budget Papers, (April 13, 1983) at 30.

${ }^{53}$ See Michael H. Hall and Sandra L. Bozzo, "Trends in Individual Donations: 1984-1996" (Fall 1997), Canadian Centre for Philanthropy Research Bulletin, Vol. 4, no. 4, at 2 (Table 1).

${ }^{54}$ Ibid.

${ }^{55}$ See Deeg, supra note 43 at 17 (Table IIIf); and Hall and Bozzo, supra note 53 at 2 (Table 1).

${ }^{56}$ Calculated from figures presented in Deeg, supra note 43 at 17 (Table IIIf).

${ }^{57}$ See paragraph 38(a) of the Act as it read prior to 1988. See also paragraph 39(1)(a) of the Act, which defines a "capital gain", and paragraph 40(1)(a) of the Act, which contains a verbal formula setting out the computation of a gain.

${ }^{58}$ S.C. 1988 , c. 55 , s. 19.

${ }^{59}$ Carter Commission, supra note 48 at 57.

${ }^{60}$ See paragraph 69(1)(b), which applies to gifts inter vivos, and subsection 70(5), which applies to capital property transferred at death.

${ }^{61}$ See Carter Commission, supra note 48 at 225-26.
} 
annual ceiling on deductible contributions) but be required to include $\$ 2,000$ (half the gain) in computing his or her income for the year, resulting in a net deduction of $\$ 3,000$.

Even before the amendments were enacted, concerns were express about imposing a tax on gifts of appreciated property to charities. ${ }^{62}$ According to Commons and Senate Committees examining the proposed legislation, gifts of appreciated property should be non-taxable but deductible only to the extent of their cost to the donor, not their market value at the time of the gift. ${ }^{63}$ In the above example, therefore, the taxpayer would not be taxable on any part of the $\$ 4,000$ accrued gain, but would be able to deduct only $\$ 1,000$, representing the cost of the asset to the taxpayer.

Although the federal government initially rejected these proposals, the Act was amended in 1972, shortly after the new rules came into effect, to allow taxpayers making a gift of appreciated property to elect any amount between the cost of the property and its fair market value at the time of the gift, which would apply both to determine the amount of any gain recognized for tax and the amount deductible as a charitable contribution. ${ }^{64}$ As a result, the taxpayer in the above example could select any amount between $\$ 1,000$ and $\$ 5,000$ which would determine both the proceeds for the computation of any gain and the amount of the available deduction. Since only half the gain was taxable while the elected amount was fully deductible, however, the only circumstance in which it was not more advantageous to designate the full fair market value is where the ability to claim the deduction was limited by the 20 percent ceiling. ${ }^{65}$ Indeed, by including only one half of the capital gain in computing the donor's income while permitting a deduction for the fair market value of the gift, the Canadian tax system created an added incentive for charitable donations of appreciated property. ${ }^{66}$

While this amendment was consistent with the recommendations of the Commons and Senate Committees, it did not go as far as others, most notably representatives from private museums recommended. Emphasizing the need to compete for donations with American museums, these representatives suggested that gifts of appreciated property should be non-taxable and fully deductible based on their fair market value at the time of the gift, as is the case in the United States. ${ }^{67}$ On this basis, the taxpayer in the above example would be able to deduct the $\$ 5,000$ value of the asset at the time of the gift (subject to the annual ceiling), without having to include any portion of the $\$ 4,000$ accrued gain, resulting in a net deduction of $\$ 5,000$.

Among U.S. tax theorists, the exemption from capital gains tax on gifts of appreciated property has been widely criticized. ${ }^{68}$ According to William Andrews, for example, the additional "subsidy or

\footnotetext{
${ }^{62}$ See the discussion in Bird and Bucovetsky, supra note 19 at 23-28.

${ }^{63}$ See ibid. at 25.

${ }^{64}$ See former subsection $110(2.2)$, added by S.C. 1973-74, c. 14, subsec. 35(7). This rule is now subsection 118.1(6) of the Act.

${ }^{65}$ See Bird and Bucovetsky, supra note 19 at 26.

${ }^{66}$ See ibid. at 26-28.

${ }^{67}$ See ibid. at $24-25$.

${ }^{68}$ See, e.g., Andrews, "Personal Deductions in an Ideal Income Tax," supra note 34 at 371-72; and Goode, supra note 22 at $167-68$.
} 
artificial inducement" for philanthropic giving that is provided by this rule is both arbitrary and inequitable:

The magnitude of the subsidy is a function of the amount of unrealized appreciation in relation to the basis of the property and the taxpayer's rates of tax, being the greatest for taxpayers in highest brackets and with the most appreciation. ${ }^{69}$

Moreover, as Richard Goode explains, this approach "tempts some donors to place excessive values on their gifts, occasionally with the collusion of recipient institutions."

Notwithstanding these criticisms, subsequent amendments have introduced further incentives for gifts of appreciated property under limited circumstances. In 1977, the Act was amended to exempt from capital gains tax any gain on a gift to designated institutions of "cultural property" certified under the Cultural Property Export and Import Act. ${ }^{71}$ In this circumstance, therefore, the taxpayer in the above example would be able to deduct the full $\$ 5,000$ value of the asset at the time of the gift (subject to the annual ceiling), without including any portion of the $\$ 4,000$ accrued gain, resulting in a net deduction of $\$ 5,000$. Although statistics on the value and frequency of donations of cultural property do not appear to be available, the extremely favourable tax treatment for gifts of this kind might be expected to produce a significant increase in donations of this kind. Indeed, by providing such favourable tax treatment, this provision has encouraged a number of questionable transactions, in which taxpayers (often with the encouragement of the recipient institution) have acquired property at a relatively low cost and donated this property immediately thereafter at an assessed value well in excess of its acquisition price, resulting in a net after-tax profit to the donor. ${ }^{72}$ In response to these kinds of transactions, the Act was subsequently

\footnotetext{
${ }^{69}$ Andrews, "Personal Deductions in an Ideal Income Tax," supra note 34 at 372.

${ }^{70}$ Goode, supra note 22 at 167.

${ }^{71}$ See paragraph 39(1)(a)(i.1) of the Act, added by S.C. 1974-75-76, c. 50, s. 48, proclaimed in force from September 6, 1977.

${ }^{72}$ See, e.g., Friedberg v. The Queen, [1989] 1 C.T.C. 274, 89 D.T.C. 5115 (F.C.T.D.), where the taxpayer claimed charitable deductions in respect of two textile collections acquired for $\$ 67,500$ and $\$ 12,000$ and donated to the Royal Ontario Museum immediately thereafter at average appraised values of $\$ 496,175$ and $\$ 229,437$. At a 50 percent marginal tax rate, the tax value of the resulting deductions would have been roughly $\$ 250,000$ in respect of the first collection and $\$ 115,000$ in respect of the second, representing after-tax profit of 270 percent on the first donation and 860 percent on the second! On appeal, [1992] 1 C.T.C. 1, 92 D.T.C. 6031 (F.C.A.), the Federal Court of Appeal questioned the accuracy of the appraised values but found no basis to interfere with the trial judge's findings of fact in this respect. Nonetheless, although it upheld the taxpayer's claim in respect of the second donation, it rejected his claim in respect of the first donation on the basis that the taxpayer had never acquired title to the textiles, which were donated directly to the Museum though paid for by the taxpayer. For other cases in which artworks have been purchased at one price and immediately thereafter donated to a charitable organization at aprraised values significantly in excess of their acquisition price, see Arvisais v. M.N.R., [1993] 1 C.T.C. 2473 , 93 D.T.C. 506 (T.C.C.); Ball v. The Queen, [1993] 2 C.T.C. 2474 (T.C.C.); Ball v. The Queen, [1993] 2 C.T.C. 2475 (T.C.C.); Gardner v. The Queen, [1993] 2 C.T.C. 2480 (T.C.C.); Bouchard v. The Queen, [1993] 2 C.T.C. 2778 (T.C.C.); Whent v. The Queen, [1996] 3 C.T.C. 2542 (T.C.C.); and Paradis v. The Queen, [1996] Can. Rep. Nat. 2261 (T.C.C.). For a critical evaluation of these kinds of transactions, see Harry Erlichman, "Case Comment: Profitable Donations -- What Price Culture?" (1992), 11 The Philanthropist 3.
} 
amended to authorize Canadian Cultural Property Export Review Board to determine the fair market value of cultural gifts for which recognition is sought under the Income Tax Act. ${ }^{73}$

More recently, the Act was amended effective February 19, 1997 to reduce the taxable amount of any gain on charitable gifts of certain publicly-traded securities from three-quarters of the gain to threeeighths. ${ }^{74}$ According to supplementary information released with the 1997 Federal Budget, this provision, which has a built-in "sunset clause" according to which the low inclusion rate applies only on gifts before the year 2002 was enacted to "provide a level of tax assistance for donations of eligible capital property that is comparable to that in the U.S." 75 in order to "facilitate the transfer of appreciated capital property to charities to help them respond to the needs of Canadians." ${ }^{, 76}$ Statistics are as yet unavailable to indicate the extent to which this measure has affected amounts donated to charities and amounts claimed for income tax purposes. By limiting this added incentive to publicly-traded securities, however, it is hoped that this measure will at least provide the secure basis for valuation that appears to have been lacking with respect to gifts of cultural property.

\footnotetext{
${ }^{73}$ See subsection 118.1(10) of the Act, added by 1994, c. 7, Sch. II (1991, c. 49), subsec. 88(3), applicable to gifts made after February 20, 1990.

${ }_{75}^{74}$ See paragraph 38(a.1) of the Act, added by S.C. 1998, c. 19, s. 6.

${ }^{75}$ Department of Finance, Tax Measures: Supplementary Information (February 18, 1997). Although donations of appreciated property are fully exempt from capital gains tax in the U.S., the Canadian Department of Finance explains that a 3/8 inclusion produces a comparable level of tax assistance in Canada due to the fact that the top marginal rate of tax in Canada is greater than that in the U.S., resulting in a lower tax price of donations in Canada than in the U.S.

${ }^{76}$ Department of Finance, Tax Measures: Supplementary Information (February 18, 1997).
} 


\section{Credit}

In the 1970s and 1980s, tax theorists increasingly came to question the merits of a deduction for charitable contributions. ${ }^{77}$ Noting that a deduction is worth more to a high-income taxpayer under a progressive income tax than it is to a low-income taxpayer, and is worthless to persons whose income is too low to pay any tax, critics argued that the deduction was a regressive method of encouraging charitable donations which provided a greater level of encouragement to charities favoured by high-income donors than low-income donors. ${ }^{78}$

In 1971, for example, when federal income tax rates ranged from 16 percent on taxable income between $\$ 500$ and $\$ 2,000$ to 80 percent on taxable income exceeding $\$ 400,000{ }^{79}$ the value of the deduction for a dollar donated to charity was nil for taxpayers with taxable incomes less than $\$ 500,16$ cents for taxpayers with taxable incomes between $\$ 500$ and $\$ 2,000$, and 80 cents for taxpayers with taxable incomes exceeding $\$ 400,000$. As a result, the net after-tax cost of donating a dollar to charity was 20 cents for taxpayers with taxable incomes exceeding $\$ 400,000,84$ cents for taxpayers with taxable incomes between $\$ 500$ and $\$ 2,000$, and one dollar for taxpayers with taxable incomes less than $\$ 500$. While top marginal rates of federal income tax were reduced significantly to 47 percent in $1972,{ }^{80} 43$ percent in $1977,{ }^{81}$ and 34 percent in $1982,{ }^{82}$ the difference between these rates and the lowest marginal rate, which was 6 percent from 1976 to $1987,{ }^{83}$ continued to imply a regressive distribution of federal tax assistance to charitable giving. ${ }^{84}$

To the extent that high and low-income taxpayers differ in the kinds of charities to which they contribute, moreover, this regressivity implied a greater level encouragement to charities favoured by highincome donors than those favoured by low-income donors. Indeed, studies indicating that high-income

\footnotetext{
${ }^{77}$ Among U.S critics of the charitable deduction, see McDaniel, supra note 36; and Dennis B. Wolkoff, "Proposal for a Radical Alternative to the Charitable Deduction," [1973] Law Forum 279. For Canadian criticisms of the deduction, see Wayne R. Thirsk, "Giving Credit Where Credit is Due: The Choice Between Credits and Deductions Under the Individual Income Tax in Canada" (1980), 28 Can. Tax J. 32; and Neil Brooks, Financing the Voluntary Sector: Replacing the Charitable Deduction (Toronto: Law and Economics Workshop Series, Faculty of Law, University of Toronto, 1981). Much of this writing is based on "tax expenditure" theory which views deductions that are not essential to the definition of the normative income tax base as a form of government spending to be evaluated as any other expenditure program. See Stanley S. Surrey, "Tax Incentives as a Device for Implementing Government Policy: A Comparison with Direct Expenditures" (1970), 83 Harv. L. Rev. 705; and Stanley S. Surrey and Paul R. McDaniel, Tax Expenditures, (Cambridge, MA: Harvard University Press, 1985).

${ }^{78}$ See, e.g. Thirsk, supra note 77 at 37, explaining that: "Under the present system, the price of charitable donations is significantly cheaper if made by a wealthy donor rather than a poor one. Consequently, the charities favoured by the rich receive greater encouragement than those patronized by the poor." See also Wolkoff, supra note 77 at 286-87.

${ }^{79}$ See subsection 32(1) of the 1952 Income Tax Act, R.S.C. 1952, c. 148.

${ }^{80}$ See former subsection 117(1) of the Act, enacted by S.C. $1970-71-72$, c. 63, s. 1.

${ }^{81}$ See former subsection 117(5.1) of the Act, added by S.C. 1976-77, c. 10, subsec. 52(2).

${ }^{82}$ See former subsection 117(5.2) of the Act, enacted by S.C. 1980-81-82-83, c. 140, subsec. 75(2).

${ }^{83}$ See former subsections 117(5), (5.1) and (5.2) of the Act.
} 
taxpayers tend to devote a larger proportion of charitable donations to hospitals, higher education, and culture (e.g., museums and the arts), while low-income taxpayers are more likely to favour religious organizations and social welfare agencies, ${ }^{85}$ suggest that a deduction provides greater encouragement for contributions to charitable organizations devoted to health, higher education, and culture, than it does for contributions to charitable organizations devoted to religion and social welfare.

As an alternative to the deduction for charitable contributions, these critics suggested that charitable donations be encouraged by matching grants paid directly to the charitable organization, ${ }^{86}$ or by tax credits the value of which would depend not on the income level of the donor but on the total amount of charitable contributions claimed in the particular taxation year. ${ }^{87}$ According to one study published in 1977 , when federal income tax rates ranged from $6 \%$ on the first $\$ 500$ of taxable income to $43 \%$ on taxable income exceeding $\$ 60,000{ }^{88}$ a flat-rate credit set at 28 percent of each taxpayer's charitable donations claimed in each year would result in a similar level of aggregate donations and similar level of federal assistance to charitable donations in terms of foregone federal tax revenues. ${ }^{89}$ As the authors noted, however, "such a rate would imply a shift in real income from high-income to low-income taxpayers, and probably a shift in the destination of donations." ${ }^{, 90}$ More specifically, they explained:

Tax-credit schemes, since they can be expected to increase the percentage of charitable donations coming from low-income groups, will also increase the percentage going to religious institutions. Charitable organizations now heavily dependent on the wealthy would face difficult times under such a regime. ${ }^{91}$

\footnotetext{
${ }^{84}$ Since these marginal rates were increased by provincial income taxes, moreover, the differential in combined federal and provincial tax assistance for charitable giving was greater than that suggested by these federal rates alone.

${ }^{85}$ Although many of these studies are American, Canadian studies have come to a similar conclusion. Among the leading U.S. studies, see Michael K. Taussig, "Economic Aspects of the Personal Income Tax Treatment of Charitable Contributions" (1967), 20 Nat. Tas J. 1; and Martin Feldstein, "The Income Tax and Charitable Contributions: Part II - The Impact on Religious, Educational and Other Organizations" (1975), 28 Nat. Tax J. 209. For a more recent Canadian study confirming a similar pattern, see Harry Kitchen and Richard Dalton, "Determinants of Charitable Donations by Families in Canada: A Regional Analysis" (1990), 22 App. Econ. 285.

${ }^{86}$ See, e.g., McDaniel, supra note 36; Wolkoff, supra note 77; and Brooks, Financing the Voluntary Sector, supra note 77.

${ }^{87}$ See, e.g., Thirsk, supra note 77 . If the value of the credit is to depend solely on the amount donated to charity and not on the income level of the donor, the credit would have to be refundable so that individuals whose income is too low to pay tax would be eligible for a tax refund on a percentage of the value of their charitable donations. See Brooks, Financing the Voluntary Sector, supra note 77 at 23-24.

${ }^{88}$ See former subsection 117(5.1) of the Act, repealed by S.C. 1985, c. 45, subsec. 62(1).

${ }^{89}$ R.D. Hood, S.A. Martin, and L.S. Osberg, "Economic Determinants of Individual Charitable Donations in Canada" (1977), 10 Can. J. Econ. 653 at 667. The conclusion that aggregate donations and foregone tax revenues would be little changed appears to assume that the responsiveness of low-income donors to a reduction in the after-tax cost of donations offsets that of high-income donors to an increase in the after-tax costs of donations. This issue is examined at infra, Part III, Section 3. In addition, since the proposed tax credit on which this estimate is based appears to have been non-refundable, a flat-rate refundable tax credit would have to be set at a lower rate in order to maintain a similar level of aggregate donations and similar level of federal assistance to charitable donations in terms of foregone tax revenue.

${ }^{90} \mathrm{Ibid}$.

${ }^{91}$ Ibid.
} 
Although any reduction in tax incentives for high-income taxpayers could be eliminated by setting the rate of the credit equal to the top marginal rate (47 percent in 1977), this would provide even further encouragement to charitable contributions by low-income taxpayers and significantly increase the cost of the credit in terms of foregone tax revenues. ${ }^{92}$

When the Carter Commission examined the charitable deduction in 1966, it acknowledged the deduction's regressivity, explaining that "[i]f equity were the only consideration, we would propose a system of credits for charitable donations" so that "[t]he tax concession would ... be related only to the size of the donation and would not also depend upon the income of the taxpayer." ${ }^{.33}$ Emphasizing that "private philanthropy performs a worthwhile social purpose", however, the Commission feared that "[t]he credit approach would ... tend to stifle charitable giving by upper income individuals and families"94 -- implicitly assuming that any credit would be set at a rate lower than the top marginal rate. ${ }^{95}$ Consequently, it concluded, "the fundamental feature of the present system, the deduction of charitable donations from income, should be continued. ${ }^{, 96}$

Although the Commission did not explain why the risk of a reduction in charitable giving by "upper income individuals and families" justified the continuation of a deduction which it itself considered inequitable, two arguments might be imagined. First, to the extent that high-income taxpayers are more responsive to changes in the after-tax cost of charitable giving than low-income taxpayers, ${ }^{97}$ any reduction in the rate of tax assistance for high-income taxpayers would be expected to cause a greater reduction in charitable donations than any increase in charitable donations induced by a comparable increase in the rate of tax assistance for low-income taxpayers. On this basis, a deduction for charitable donations might be characterized as a more efficient method of encouraging charitable contributions than a credit. Indeed, a Canadian study published in 1986 estimated that a revenue-neutral tax credit of 29 percent would cause aggregate donations to fall by $\$ 10$ million, while a high-rate credit of 50 percent would increase aggregate donations by only $\$ 6$ million at a cost in terms of foregone revenue of $\$ 422$ million. ${ }^{98}$

Alternatively, to the extent that charitable organizations which tend to be favoured by high-income taxpayers (i.e., hospitals, universities, and cultural institutions) are considered more deserving of public support than those favoured by low-income taxpayers (religious organizations and social welfare agencies),

\footnotetext{
${ }^{92}$ Ibid.

${ }^{93}$ Carter Commission, supra note 48 at 222.

${ }^{94}$ Ibid.

${ }^{95}$ While the assumption that a credit would be set at a rate lower than the top marginal rate might have been reasonable -- since the cost of federal assistance in terms of foregone revenues might have been expected to increase significantly otherwise -- the Commission might have made this assumption clear.

${ }^{96}$ Carter Commission, supra note 48 at 222.

${ }^{97}$ Until the mid-1970s, the prevailing view appears to have been that low-income taxpayers were largely unresponsive to changes in the after-tax cost of charitable giving. See, e.g., Henry Aaron, "Federal Encouragement of Private Giving," in Tax Impacts on Philanthropy, Symposium conducted by the Tax Institute of America (Princeton: Tax Institute of America, 1972) 211. Subsequent studies are much less certain. See, e.g., Charles T. Clotfelter, Federal Tax Policy and Charitable Giving, (Chicago: University of Chicago Press, 1985) at 66-71. I return to this issue at infra, Part III, Section 3.
} 
a deduction might be preferred to a credit on the grounds that it better targets tax assistance to these preferred organizations. As Faye Woodman has argued:

Simply, an argument may be made that some institutions are richer contributors to the social, cultural, and intellectual mosaic than others. Hence, it may be possible to justify a system of deduction that is skewed in the direction of the favourite charities of upper-income taxpayers. ${ }^{99}$

Indeed, Woodman speculates that this was the key reason why the Carter Commission recommended that the deduction for charitable contributions be retained. ${ }^{100}$

Whatever reason or reasons caused the Carter Commission to recommend the continuation of the charitable deduction in 1966, the federal government ceased to be convinced by these arguments in 1987, at which time it announced that it would amend the Act by converting the deduction to a credit designed to "increase fairness by basing tax assistance on the amount given, regardless of the income level of the donor." upper income individuals and families", however, the government also indicated that the credit would be designed to "maintain a substantial incentive for charitable giving." this result only at a substantially increased cost in terms of foregone tax revenues, ${ }^{103}$ moreover, the government settled on a "two-tier credit" equal to the lowest marginal rate of tax on charitable donations claimed up to $\$ 250,{ }^{104}$ and the highest marginal rate of tax on amounts exceeding this threshold. ${ }^{105}$ According to supplementary information accompanying the White Paper in which these reforms were announced, the proposed amendment was expected to cost an additional $\$ 80$ million per year, increasing the aggregate level of federal tax assistance for charitable giving to $\$ 900$ million in $1988 .{ }^{106}$

When the Act was amended for 1988 and subsequent taxation years, the rates of federal income tax were set at 17 percent on taxable income up to $\$ 27,500,26$ percent on taxable income up to $\$ 55,000$, and 29 percent on taxable income exceeding $\$ 55,000 .{ }^{107}$ As a result, under the formula enacted in $1988,{ }^{108}$ the credit for charitable contributions equaled 17 percent on the first $\$ 250$ claimed for the year and 29 percent on amounts exceeding \$250. For 1994 and subsequent taxation years, the credit equals 17 percent on the

\footnotetext{
${ }^{98}$ Graham Glenday, Anil K. Gupta, and Henry Pawlak, "Tax Incentives for Personal Charitable Contributions" (1986), 68 Rev. Econ. \& Stats. 688 at 692.

${ }^{99}$ See, e.g., Faye Woodman, "The Tax Treatment of Charities and Charitable Donations Since The Carter Commission: Past Reforms and Present Problems" (1988), 26 Osgoode Hall L.J. 537 at 575. I return to this issue at infra, Part III, Section 4.

${ }^{100} \mathrm{Ibid}$. at $573-74$.

${ }^{101}$ Hon. Michael Wilson, Tax Reform 1987: White Paper, (Ottawa: Minister of Supply and Services, 1987) at 32 .

${ }^{102}$ Ibid.

${ }^{103}$ See supra, text accompanying notes 92 and 98.

${ }^{104}$ For 1994 and subsequent taxation years, this threshold was lowered to $\$ 200$. S.C. 1995, c. 3, s. 34.

${ }^{105}$ Wilson, Tax Reform 1987, at 32.

${ }^{106}$ Department of Finance, Supplementary Information Relating to Tax Reform Measures, (Ottawa: Minister of Supply and Services, 1987) at 10.

${ }^{107}$ See subsection $117(2)$ of the Act, added by S.C. 1988, c. 55, subsec. 90(2). The rate brackets established by this provision are partially indexed by section 117.1 , and are now $\$ 29,590$ and $\$ 59,180$.

${ }^{108}$ See subsection 118.1(3) of the Act, added by S.C. 1988 , c. 55, s. 92.
} 
first $\$ 200$ claimed for the year and 29 percent on amounts exceeding $\$ 200$. When federal surtaxes and provincial taxes are taken in to account, the credit is equal to roughly 25 percent on amounts up to $\$ 200$ and 50 percent on amounts over this threshold. As a result, the after-tax cost of charitable gifts is approximately 75 cents for each dollar up to $\$ 200$ and 50 cents for each dollar over $\$ 200$.

For taxpayers paying tax at the lowest marginal rate, therefore, the credit functions as a deduction for annual contributions up to $\$ 200$ and an additional incentive on charitable gifts exceeding these amounts. For taxpayers paying tax at the top marginal rate, the credit provides roughly half the assistance as a deduction for annual charitable gifts up to $\$ 200,{ }^{109}$ but functions as a deduction for annual amounts exceeding \$200. For taxpayers paying tax at the 26 percent rate, the credit is worth less a deduction for amounts up to $\$ 200$ but more than a deduction for amounts over this threshold.

Although the two-tier credit appears to be more equitable than the deduction, providing an "equal reward for effort in giving by donors in all income brackets in contrast to the ... deduction system which provides greater reward for those in higher income brackets, ${ }^{110}$ its distributional impact differs little from a deduction. On the contrary, since average contributions by low-income taxpayers are less than or not much greater than the $\$ 200$ threshold, while average contributions by high-income taxpayers greatly exceed the $\$ 200$ threshold, a significant proportion of charitable donations by low-income taxpayers are creditable at the 17 percent rate, whereas most charitable contributions by high-income taxpayers are creditable at the 29 percent rate. As Table 1 indicates, while the credit is on average somewhat more valuable than a deduction for claimants with incomes of $\$ 10,000$ to $\$ 30,000$ and slightly less valuable than a deduction for claimants

\footnotetext{
${ }^{109}$ While a $\$ 100$ deduction would be worth roughly $\$ 50$ to a taxpayer paying tax at the top marginal rate, for example, the credit is worth roughly $\$ 25$ on an annual contribution of $\$ 100$.

${ }^{110}$ Department of Finance, Supplementary Information Relating to Tax Reform Measures, at 10.
} 
Table 1

Average Effective Federal Charitable Tax Credit Rates by Income Class (1996) ${ }^{111}$

\begin{tabular}{|c|c|c|c|}
\hline Income Class (\$) & $\begin{array}{c}\text { Average Donation for } \\
\text { Taxfilers Claiming } \\
\text { Donations }(\$)\end{array}$ & $\begin{array}{c}\text { Average Federal } \\
\text { Charitable Tax Credit } \\
(\$)\end{array}$ & $\begin{array}{c}\text { Average Effective } \\
\text { Federal Charitable Tax } \\
\text { Credit Rate (\%) }\end{array}$ \\
\hline $1-10,000$ & 196.12 & 33.34 & 17.0 \\
\hline $10,000-30,000$ & 468.08 & 111.74 & 23.9 \\
\hline $30,000-60,000$ & 617.80 & 155.16 & 25.1 \\
\hline $60,000-100,000$ & 939.23 & 248.38 & 26.4 \\
\hline $100,000-250,000$ & $2,177.05$ & 607.34 & 27.9 \\
\hline over 250,000 & $11,165.00$ & $3,123.85$ & 28.8 \\
\hline
\end{tabular}

with incomes of $\$ 60,000$ to $\$ 100,000$, its impact is indistinguishable from a deduction for claimants with incomes less than $\$ 10,000$, and largely indistinguishable from a deduction for claimants with incomes from $\$ 30,000$ and $\$ 60,000$ or over $\$ 100,000$. Since the credit is not refundable, moreover, it provides no assistance to charitable giving by taxpayers whose income is too low to pay any tax.

While these figures indicate that the two-tier credit has, as the government intended, preserved "a substantial incentive for charitable giving" particularly among high-income contributors, they also demonstrate that the level of tax assistance for charitable contributions continues to depend on the income level of the donor as it did under the deduction. Indeed, one commentator has suggested that the two-tier credit can be regarded "a deduction masquerading as a credit". 113 Not surprisingly, therefore, the conversion from a deduction to a credit appears to have had little impact on the value of charitable donations claimed for tax purposes, which increased only slightly from 1987 to $1988 .{ }^{114}$ Nor does it seem to have had much affect on the distribution of charitable donations by income group, which, as Table 2 demonstrates, changed very little from 1987 to 1988.

\footnotetext{
${ }^{111}$ Calculated from figures in Revenue Canada, Taxation Statistics on Individuals: 1996 Tax Year, (Ottawa: Minister of Supply and Services, 1998).

${ }^{112}$ Calculated as 17 percent of the first $\$ 200$ of average donations and 29 percent of amounts exceeding $\$ 200$.

${ }^{113}$ E. Blake Bromley, "Charity, Philanthropy and Stewardship: A Philosophical Perspective on Tax Reform" (Winter 1988), 7 The Philanthropist 4 at 5.

${ }^{114}$ See Hall and Bozzo, supra note 53 at 2 (Table 1).
} 
Table 2

Distribution of Taxfilers and Charitable Donations Claimed by Income Class $(1987,1988){ }^{115}$

\begin{tabular}{|c|c|c|c|c|}
\hline Income Class (\$) & $\begin{array}{c}\text { Percentage of } \\
\text { Taxfilers } \\
(1987)\end{array}$ & $\begin{array}{c}\text { Percentage of Charitable } \\
\text { Donations Claimed } \\
(1987)\end{array}$ & $\begin{array}{c}\text { Percentage of } \\
\text { Taxfilers } \\
(1988)\end{array}$ & $\begin{array}{c}\text { Percentage of Charitable } \\
\text { Donations Claimed } \\
(1988)\end{array}$ \\
\hline $1-10,000$ & 31.3 & 2.5 & 29.1 & 2.2 \\
\hline $10,000-30,000$ & 44.6 & 33.4 & 44.6 & 31.1 \\
\hline $30,000-60,000$ & 21.0 & 37.7 & 22.3 & 37.8 \\
\hline $60,000-100,000$ & 2.3 & 10.9 & 3.0 & 12.0 \\
\hline $100,000-250,000$ & 0.7 & 8.5 & 0.9 & 8.9 \\
\hline over 250,000 & 0.11 & 7.0 & 0.18 & 8.1 \\
\hline
\end{tabular}

By adopting a two-tier credit rather than a flat-rate credit set at the top marginal rate of tax, however, the government was able to minimize the cost of the credit in terms of foregone revenues. In fact, despite the government's expectation that tax assistance for charitable giving would increase to roughly $\$ 900$ million in $1988,{ }^{116}$ government figures indicate that the cost of the charitable credit was $\$ 670$ million in 1988, \$750 million in 1989, \$815 million in 1990, \$845 million in 1991, \$865 million in 1992, $\$ 880$ million in 1993, and reached $\$ 900$ million only in $1994 .{ }^{117}$ By lowering marginal rates of tax and the associated rates of the charitable credit, therefore, the 1987 tax reforms actually reduced federal assistance for charitable giving.

\section{Ceilings}

As indicated earlier, the deduction for charitable contributions that was enacted in 1930 was limited to a maximum of 10 percent of the taxpayer's income for the year. Although the U.S. provision on which the Canadian deduction was based, contained a ceiling of 15 percent of the taxpayer's income, a 10 percent ceiling was selected in Canada on the basis that "it originated in the Mosaic Law and the practice of tithing." 118

${ }^{115}$ Calculated from figures in Revenue Canada, Taxation Statistics on Individuals: 1987 Tax Year, (Ottawa: Minister of Supply and Services, 1989); and Revenue Canada, Taxation Statistics on Individuals: 1988 Tax Year, (Ottawa: Minister of Supply and Services, 1990).

${ }^{116}$ Supra note 106 and accompanying text.

${ }^{117}$ See Government of Canada, Personal Income Tax Expenditures, (Ottawa: Department of Finance, 1992) at 14; Government of Canada, Personal and Corporate Income Tax Expenditures, (Ottawa: Department of Finance, 1993) at 19; and Government of Canada, Tax Expenditures, (Ottawa: Department of Finance, 1997) at 29.

${ }^{118}$ Watson, supra note 18 at 9, citing comments by then Leader of the Opposition R.B. Bennett. 
Although this rationale for a maximum ceiling on deductible contributions might suggest that contributions up to 10 percent of a taxpayer's annual income were regarded as in some sense obligatory and therefore meriting a deduction, while those exceeding 10 percent were considered discretionary and nondeductible, ${ }^{119}$ a more prevalent explanation involves the concern that without an income-related ceiling high-income taxpayers might be able to eliminate their tax liabilities altogether by making substantial charitable gifts. ${ }^{120}$ As one American commentator has observed, although this outcome might be considered acceptable to the extent that donors contribute to various public purposes qualifying for a charitable deduction (or credit), it would enable large donors to avoid any obligation to support the cost of public goods and services determined by the elected representatives of the community as a whole. ${ }^{121}$ Thus, he explains, the existence of a maximum limit on deductible (or creditable) contributions in any year "reflects a judgment ... that although charitable contributions are important and should be encouraged, every taxpayer should bear part of the burden of supporting the government." ${ }^{, 22}$ In this respect, he adds, a maximum limit on deductible (or creditable) contributions functions as "a mechanism to effectuate an appropriately limited consumer sovereignty over social service expenditures."

Consistent with the second rationale for a maximum limit on deductible (or creditable) donations, the ceilings in Canada and the United States have increased significantly since the deductions were enacted -- well beyond the 10 percent ratio established by the Mosaic law and the practice of tithing. In the United States, the ceiling was increased to 50 percent, where it currently remains. ${ }^{124}$ In Canada, the general ceiling was increased to 20 percent in $1972,{ }^{125} 50$ percent in $1996,{ }^{126}$ and 75 percent for 1997 and subsequent taxation years. ${ }^{127}$ In each case, these amendments were designed to "encourage larger donations to charitable organizations". ${ }^{228}$

In addition to these increases in the general ceiling, as a further incentive for charitable giving, specific categories of gifts have been subject to higher limits or no limit at all. In 1939, for example, when the general ceiling on deductible contributions was 10 percent of the donor's income, a separate ceiling of 50 percent was enacted for donations to "any patriotic organization or institution in Canada

\footnotetext{
${ }^{119}$ I return to this argument in favour of a deduction for charitable contributions at infra, Part III, Section 1.

${ }^{120}$ See, e.g., Bird and Bucovetsky, supra note 19 at 17, suggesting that "it seems highly probable that this limitation was motivated by the desire to reduce the possibility of abuse of the deduction for purposes of tax avoidance."

${ }^{121}$ Peter J. Wiedenbeck, "Charitable Contributions: A Policy Perspective" (1985), 50 Missouri L. Rev. 85 at $115-17$.

${ }^{122}$ Ibid. at 115 .

${ }^{123}$ Ibid. at 117.

${ }^{124}$ See ibid. at $110-17$.

${ }^{125}$ See former paragraph 110(1)(a) of the Act, enacted by S.C. 1970-71-72, c. 63, s.1. This increase went beyond the recommendation of the Carter Commission, which suggested that the ceiling be increased to 15 percent. See Carter Commission, supra note 48 at 223-24.

${ }^{226}$ S.C. 1997 , c. 25 , s. 26.

${ }^{127}$ S.C. 1998 , c. 19 , subsec. $22(14)$.

${ }^{128}$ Department of Finance, Tax Measures: Supplementary Information (March 6, 1996). See also Department of Finance, Tax Measures: Supplementary Information (February 19, 1997), suggesting that the increased ceiling would "encourage more donations by providing an enhanced ability to claim tax assistance in the year of donation for the most generous donors."
} 
which hereafter receives the written approval of the Secretary of State of the Dominion of Canada." ${ }^{129}$ In 1941, this ceiling was replaced by a lower ceiling of 40 percent applicable for donations to "the fund registered under The War Charities Act, 1939, under the name of The Canadian War Services Fund" provided that such funds were subscribed on before April 7, 1941 and paid before December 31, 1941 . $^{130}$ Thereafter, the ceiling for all gifts returned to 10 percent of the donor's income for the year.

In 1950, however, gifts to the federal government were made subject to a separate deduction without any limit. ${ }^{131}$ For 1968 and subsequent taxation years, this provision was amended to include gifts to a province as well as the federal government. ${ }^{132}$ In 1977, when the Act was amended to exclude gifts of cultural property from capital gains tax, ${ }^{133}$ a separate deduction without any ceiling was also enacted for gifts of this kind. ${ }^{134}$ Although these specific deductions were repealed when the general deduction was converted to a credit in $1988,{ }^{135}$ the credit for these two categories of gifts continues to be available without any income-related limit. ${ }^{136}$ In 1995, moreover, the Act was amended yet again to exclude certain gifts of ecologically sensitive land from any income-related ceiling. ${ }^{137}$ Noting that the value of such land "may often be high relative to the donor's income", supplementary information accompanying the announced reform indicated that the ceiling for gifts of this kind would be eliminated in order to "further encourage the conservation and protection of Canada's environmental heritage". ${ }^{138}$

In addition to these three categories of gifts, recent amendments have also increased the ceiling on creditable gifts to include the full amount of taxable capital gains from gifts of appreciated capital property, ${ }^{139}$ and increased the ceiling on creditable gifts made in the last two years of an individual's life to the individual's income for each of these two years. ${ }^{140}$ While the former amendment is intended "to ensure that taxpayers making gifts of appreciated capital are able to claim tax credits for the full amount of the capital gain,"

\footnotetext{
${ }^{129}$ S.C. $1939-40$, c. 6 , s. 1.

${ }^{130}$ S.C. 1941 , c. 18 , s. 7.

${ }^{131}$ See paragraph 26(1)(aa) of the 1948 Income Tax Act, added by S.C. 1950, c., 40, s. 10. This provision became paragraph 27(1)(b) of the 1952 Act, and former paragraph 110(1)(b) of the 1972 Act.

${ }^{132}$ S.C. $1967-68$, c. 38 , s. $1(2)$.

${ }^{133}$ See paragraph 39(1)(a)(i.1) of the Act, added by S.C. 1974-75-76, c. 50, s. 48, proclaimed in force from September 6, 1977.

${ }^{134}$ S.C. $1974-75-76$, c. 50 , s. 50, adding former paragraph $110(1)($ b.1).

${ }^{135}$ S.C. 1988 , c. 55 , subsec. $77(1)$. On the conversion from a deduction to a credit, see infra, Part II, Section 5.

${ }^{136}$ See paragraphs (b) and (c) of the definition of "total gifts" in subsection 118.1(1), as well as the definitions of "total Crown gifts" and "total cultural gifts" in subsection 118.1(1) of the Act.

${ }^{137}$ See paragraph (d) of the definition of "total gifts" in subsection 118.1(1), as well as the definition of "total ecological gifts" in subsection 118.1(1) of the Act, added by S.C. 1996, c. 21, subsections 23(3) and (4), applicable to gifts made after February 27, 1995.

${ }^{138}$ Department of Finance, Tax Measures: Supplementary Information, (February 27, 1995).

${ }^{139}$ See subparagraph (a)(iii) of the definition of "total gifts" in subsection 118.1(1), as amended by S.C. 1997, c. 25, s. 26, applicable to 1996 and subsequent taxation years, and S.C. 1998, c. 19, subsec. 22(4), applicable to taxation years beginning after 1996.

${ }^{140}$ See subparagraph (a)(ii) of the definition of "total gifts" in subsection 118.1(1), added by S.C. 1997, c. 25 , s. 26, applicable to 1996 and subsequent taxation years.

${ }^{141}$ Department of Finance, Tax Measures: Supplementary Information (March 6, 1996).
} 
gift is large relative to income in the last two years of life." ${ }^{142}$ In more general terms, these amendments were enacted in order to eliminate "a serious impediment to charitable giving," of appreciated property, the tax on which might otherwise exceed the allowable credit, ${ }^{144}$ and by way of bequests or legacies, which can be quite large relative to one's income in the last year of one's life. ${ }^{145}$

Interestingly, these increased ceilings, as well as recent increases in the general limit, appear to have had a dramatic impact on donations claimed for tax purposes. According to one recent study, the average inflation-adjusted value of donations claimed by taxfilers claiming charitable donations increased sharply from 1995 to 1996 by 11.7 percent, after remaining relatively constant during the period 1984 to $1995 .{ }^{146}$ More significantly, as Table 3 indicates, increases in the maximum donations that can be claimed in a taxation year have altered the distribution of charitable donations claimed by income class, significantly increasing the percentage of charitable donations claimed by the highest income groups. The extent to which this increase reflects a change in actual donations or merely in donations claimed for tax purposes remains to be determined.

\footnotetext{
${ }^{142}$ Ibid.

${ }^{143}$ Ibid.

${ }^{144}$ For a useful demonstration of this point, at a time when $1 / 2$ of each capital gain was taxable, charitable contributions were deductible, and the ceiling was 20 percent of the taxpayer's income, see Wolfe D. Goodman, "The Impact of Taxation on Charitable Giving: Some Very Personal Views," (Fall 1984) The Philanthropist 5 at 7-8, explaining that if taxpayer with with annual income of $\$ 100,000$ donated shares worth $\$ 1,000,000$ but acquired at a cost of $\$ 100,000$, the taxpayer would have include an additional $\$ 450,000(1 / 2 \times \$ 900,000)$ in computing his or her income, but be eligible for a deduction of only $\$ 110,000(.2 \times(\$ 100,000+\$ 450,000))$, creating a serious tax disincentive to the making of such a gift. ${ }^{145}$ See, e.g., J.A. Langford, "The Tax Reform Bill and the Death of a Taxpayer" (1971), 19 Can. Tax J. 513.

${ }^{146}$ See Hall and Bozzo, supra note 53 at 3.
} 
Table 3

Distribution of Taxfilers and Charitable Donations Claimed by Income Class $(1995,1996){ }^{147}$

\begin{tabular}{|c|c|c|c|c|}
\hline Income Class (\$) & $\begin{array}{c}\text { Percentage of } \\
\text { Taxfilers } \\
(1995)\end{array}$ & $\begin{array}{c}\text { Percentage of Charitable } \\
\text { Donations Claimed } \\
(1995)\end{array}$ & $\begin{array}{c}\text { Percentage of } \\
\text { Taxfilers } \\
(1996)\end{array}$ & $\begin{array}{c}\text { Percentage of Charitable } \\
\text { Donations Claimed } \\
(1996)\end{array}$ \\
\hline $1-10,000$ & 24.0 & 0.97 & 24.1 & 0.76 \\
\hline $10,000-30,000$ & 43.5 & 25.6 & 42.9 & 23.2 \\
\hline $30,000-60,000$ & 25.5 & 36.5 & 25.5 & 34.9 \\
\hline $60,000-100,000$ & 5.5 & 16.6 & 5.9 & 17.0 \\
\hline $100,000-250,000$ & 1.3 & 10.6 & 1.4 & 11.3 \\
\hline over 250,000 & 0.23 & 9.8 & 0.27 & 12.7 \\
\hline
\end{tabular}

\section{Carryovers}

To the extent that the Income Tax Act limited deductions (and later credits) for charitable donations to a maximum percentage of the donor's annual income, it was inevitable that individuals with little or no taxable income and individuals who had made substantial charitable contributions relative to their annual incomes were likely to face limits on the extent to which otherwise eligible gifts would be recognized for tax purposes. In 1957, therefore, when the ceiling was 10 percent of the donor's income for the year, the Act was amended to permit taxpayers whose charitable donations were not deductible in the year of the gift to carry the excess forward to the next taxation year. ${ }^{148}$ According to one commentator, this amendment was "a minor concession to supporters of the universities who were urging an increase in the 10 percent limit". ${ }^{149}$ Although the ceiling was increased to 20 percent in 1972, the Act was further amended in 1981 to allow taxpayers whose charitable contributions were not deductible in the year of the gift to carry the excess forward for five years. ${ }^{150}$

In 1984, this carryover was amended yet again to allow taxpayers to claim charitable contributions in the year of the gift or any of the following five taxation years, even if the amount could have been deducted in the year when the gift was made. ${ }^{151}$ This amendment, which radically transformed the carryover from a "minor concession" to lessen the impact of the income-related ceiling into an instrument

${ }^{147}$ Calculated from figures in Revenue Canada, Taxation Statistics on Individuals: 1995 Tax Year, (Ottawa: Minister of Supply and Services, 1997); and Revenue Canada, Taxation Statistics on Individuals: 1996 Tax Year, (Ottawa: Minister of Supply and Services, 1998).

${ }^{148}$ S.C. 1957, c. 29, s. 7(1), amending then paragraph 27(1)(a) of the 1952 Income Tax Act.

${ }^{149}$ Watson, supra note 18 at 11.

${ }^{150}$ S.C. $1980-81-82-83$, c. 140 , subsec 57(1), amending former paragraph 110(1)(a) of the Act. See also S.C. 1980-81-92-83, c. 140, subsec. 65(2), amending former paragraphs 110(1)(b) and (b.1) of the Act.

${ }^{151}$ S.C. 1985 , c. 45 , subsec. 54(1), amending former paragraph 110(1)(a) of the Act. 
for tax planning, has enabled taxpayers to aggregate the value of their contributions over a six-year period and claim the value of these gifts in the year or years in which it is most advantageous to do so. Under the deduction available prior to 1988 , the optimal strategy turned on the year in which the taxpayer expected to pay tax at the highest marginal rate, in which year the deduction would be most valuable, subject to the offsetting cost associated with a delay in obtaining the value of the deduction. Since the enactment of the two-tier credit in 1988, the optimal strategy may involve "bunching" claims in a single year, since taxpayers can thereby maximize the amount eligible for a credit at the higher rate, subject again to the offsetting cost associated with a delay in obtaining the value of the credit.

Although the impact of this optional carryforward on amounts actually donated to charities is uncertain, this amendment is likely to have decreased the incidence of claims made in any particular year and increased the average size of claims when made. In addition, by making the value of the deduction or credit depend not only on the amount contributed, but the year in which the amount is claimed, this carryover has significantly increased the planning and record-keeping costs that taxpayers are likely to face in claiming charitable contributions for tax purposes. While at least some carryforward seems justified so long as the charitable credit is non-refundable, it is unclear why this carryforward should be optional and not limited to the amount of any excess that cannot be claimed in the taxation year of the gift.

In addition to this carryforward, the Act also authorizes a limited carryback for charitable gifts made in the year of the taxpayer's death. According to subsection 118.1(4) of the Act, ${ }^{152}$ a gift made in the year in which the taxpayer dies may be claimed in the year preceding the taxpayer's death to the extent that it is not claimed in the year of the taxpayer's death. Since charitable gifts can be quite large relative to one's income in the last year of one's life, and obviously cannot be spread out over subsequent years, it seems reasonable to allow a limited carryback in this circumstance.

\section{Transfer of Receipts}

According to the Act, charitable contributions must be claimed by the individual who makes the gift. ${ }^{153}$ As an administrative practice, however, Revenue Canada allows either spouse to claim charitable donations made by either spouse or their dependants, regardless of the name to whom the receipt is issued. As a result, as Arthur Drache explains, "[u]nder the deduction system, it always made sense for the higher income spouse to claim the donations for tax purposes." ${ }^{154}$ Likewise, under the two-tier credit introduced

\footnotetext{
${ }^{152}$ Added by S.C. 1988 , c. 55 , s. 92 .

${ }^{153}$ See the definitions of "total charitable gifts", "total Crown gifts", "total cultural gifts" and "total ecological gifts" in subsection 118.1(1) of the Act, each of which refers to "a gift ... made by the individual".

${ }^{154}$ Arthur Drache, Canadian Tax Treatment of Charities and Charitable Donations, (Scarborough: Carswell, 1998), Chapter 11 at 13.
} 
in 1988, it makes sense for one spouse to claim charitable contributions made by both spouses and their dependants in order to maximize the amount eligible for a credit at the higher rate. ${ }^{155}$

Since individual members of a family could easily arrange for only one member of the family to make all charitable donations, Revenue Canada's administrative practice makes sense as a way of extending the advantages of aggregation to less sophisticated taxpayers who might not adopt this behavioural response. If the credit were converted to a flat-rate, however, much of the incentive to transfer receipts would disappear, though it would remain where the income of the actual donor is too low to pay tax or the aggregate amount of the actual donor's gifts exceeds the income-related ceiling for the year.

In any event, the ability to transfer receipts, like the ability to carryover claims from one year to another, is likely to decrease the frequency of claims among taxfilers and increase the average size of claims made by each taxpayer claiming the credit. ${ }^{156}$ As a result, statistics indicating that only 26.9 percent of taxfilers claimed charitable contributions in 1996 cannot be read to suggest that only 26.9 percent of individuals made charitable donations in 1996. Nor do statistics showing an average donation of $\$ 728$ among taxfilers claiming charitable contributions in 1996 suggest that these individuals actually contributed an average of $\$ 728$ to charities in 1996. Whether Revenue Canada's administrative practice affects either the frequency or amount of claims or (more importantly) the frequency and amount of charitable donations is uncertain.

\section{Rationale and Design}

Having examined the history and structure of the Canadian tax credit and related provisions governing the tax treatment of charitable contributions by individuals, it remains to consider the reasons why these gifts might be taken into account in computing a taxpayer's income tax and the resulting manner in which these gifts should be taken into account. This Part evaluates four possible rationales for recognizing charitable contributions in the income tax, considering the design characteristics suggested by each of these rationales, and developing a conceptual framework to evaluate the Canadian credit.

\footnotetext{
${ }^{155}$ If both spouses are in a taxpaying position, it does not matter which spouse actually claims the credit. Since the credit is non-refundable, however, it is of no value to a spouse whose income is insufficient to pay any tax. In this circumstance, it makes sense for a spouse in a taxpaying position to claim the charitable donations.

${ }^{156}$ Hall and Bozzo, supra note 53 at 1-2.
} 


\section{Defining Income}

In computing an individual's income for the purposes of an income tax, deductions are generally allowed for reasonable expenses that must be incurred in order to produce the income. In computing a taxpayer's income from a business or property, for example, the Income Tax Act allows taxpayers to deduct outlays or expenses "made or incurred by the taxpayer for the purpose of gaining or producing income from the business or property". ${ }^{157}$ In addition, income taxes often allow further deductions for involuntary expenses, such as necessary medical expenses, ${ }^{158}$ which reduce the taxpayer's taxable capacity. These deductions ensure that tax burdens are distributed in an equitable manner, consistent with a reasonable measure of each taxpayer's ability to pay.

In this light, it would appear, provisions recognizing a taxpayer's charitable contributions cannot be justified as being necessary to the definition of an equitable measure of taxable income, but must be explained on the basis of some extrinsic social or economic purpose that the provisions are designed to achieve. $^{159}$ Indeed, when the Canadian deduction was introduced in $1930,{ }^{160}$ its apparent purpose was not to ensure that each taxpayer's ability to pay would be defined in an equitable manner, but to "encourage wealthy taxpayers to contribute to "useful, philanthropic and religious purposes",161 and to promote "public policy and the general good of the community."162 Likewise, the design of the two-tier credit and increases in the income-related ceiling for creditable donations were designed to "maintain a substantial incentive for charitable giving" 163 and "encourage larger donations to charitable organizations. ${ }^{164}$

\footnotetext{
${ }^{157}$ See paragraph 18(1)(a) of the Act. As a general rule, deductions are allowed in computing the taxpayer's "profit" from the business or property under subsection 9(1) of the Act. See, e.g., The Royal Trust Company v. M.N.R., [1957] C.T.C. 32, 57 D.T.C. 1055 (Exch. Ct.). Limitations on allowable deductions in computing a taxpayer's income from an office or employment represent a departure from this general principle. See subsection 8(2) of the Act, which limits allowable deductions in computing a taxpayer's income from an office or employment to those specifically permitted by section 8 of the Act.

${ }^{158}$ Until 1988, the Canadian Income Tax Act permitted these expenses to be deducted to the extent that they exceed 3 percent of the taxpayer's net income. See former paragraph 110(1)(c) of the Act, repealed by added by S.C. 1988, c. 55, subsec. 77(1). As with the charitable deduction, this deduction was converted to a credit in effective for 1988 and subsequent taxation years. See subsection 118.2, added by S.C. 1988, c. 55, s 92. For a persuasive argument that necessary medical expenses should be recognized as a deduction in computing taxable income, see Robin W. Boadway and Harry M. Kitchen, Canadian Tax Policy, 2nd edn. (Toronto: Canadian Tax Foundation, 1984) at 69-71.

${ }^{159}$ See, e.g., McGregor, supra note 25 at 441 , observing that: "The allowance of a tax deduction for charitable contributions cannot be justified -- and has not been justified -- by any concept within an income tax system; any justification it has is social and economic." See also Rendall, supra note 20 at 152 , arguing that "the charitable deduction has a very uncertain, and uneasy rationale. It is not a deduction to recognize the cost of earning income, nor a hardship relief to recognize reduced ability to pay tax. Indeed, it really represents a consumption expense. Unlike other expenditures which result from consumption decisions, this one is encouraged by way of a tax deduction. Accordingly, it would seem to be indisputable that the relief should be subjected to some requirement to establish its continuing justification; at the very least, its proponents should be prepared to demonstrate its effectiveness if not to justify its purpose."

${ }^{160}$ See supra, Part II, Section 1.

${ }^{161}$ Rendall, supra note 20 at 153.

${ }^{162}$ McGregor, supra note 25 at 448.

${ }^{163}$ Hon. Michael Wilson, Tax Reform 1987: White Paper, at 32.
} 
Notwithstanding this conclusion, advocates of a deduction for charitable contributions have advanced three reasons why such a deduction should be regarded as a necessary measure for defining taxable income. First, as U.S. tax theorist Boris Bittker has argued, "charitable contributions represent a claim of such a high priority" that they should be regarded as largely involuntary obligations which should be excluded "in determining the amount of income at the voluntary disposal of the taxpayer in question.,"165 Alternatively, as U.S. tax theorist William Andrews has argued, to the extent that tax burdens are based on the aggregate of a taxpayer's personal consumption and accumulation, ${ }^{166}$ they should not apply to charitable gifts which enter into the consumption of needy recipients (in the case of "alms for the poor") or provide non-exclusive or public goods and services (in the case of "philanthropy more broadly defined" to include contributions to hospitals, education and culture). ${ }^{167}$ Similarly, as one Canadian commentator has argued:

... the tax deduction simply removes the tax penalty which would otherwise result if taxpayers had to pay taxes on income which they had voluntarily chosen not to receive personally but to redirect to registered charities or other qualified donees. ${ }^{168}$

Finally, as Bittker has also argued, a deduction for charitable contributions maintains equity both between individuals who donate non-taxable services to charitable organizations and individuals who earn taxable income from which they make donations of cash or property, ${ }^{169}$ and between individuals who are able to

${ }^{164}$ Department of Finance, Tax Measures: Supplementary Information (March 6, 1996). See also Department of Finance, Tax Measures: Supplementary Information (February 19, 1997), suggesting that the increased ceiling would "encourage more donations by providing an enhanced ability to claim tax assistance in the year of donation for the most generous donors."

${ }^{165}$ Bittker, supra note 34 at 165 . For a similar argument, see also Mark P. Gergen, "The Case for a Charitable Contribution Deduction" (1988), 74 Va. L. Rev. 1393 at 1426-33.

${ }^{166}$ Andrews, "Personal Deductions in an Ideal Income Tax," supra note 34 at 317-31. This definition of the ideal personal income tax base is derived from Henry C. Simons, Personal Income Taxation: The Definition of Income as a Problem of Fiscal Policy, (Chicago: University of Chicago Press, 1938) at 50: "Personal income may be defined as the algebraic sum of (1) the market value of rights exercised in consumption and (2) the change in the value of the store of property rights between the beginning and end of the period in question."

${ }^{167}$ Andrews, "Personal Deductions in an Ideal Income Tax," supra note 34 at 344-70.

${ }^{168}$ Bromley, supra note 113 at 5. See also Wolfe D. Goodman, "Correspondence" (1980), 28 Can. Tax J. 399, contending that: "When a person makes a charitable donation, the money he parts with is no longer available for his use. ... In plain English, after a person makes a charitable donation, he has less money to live on."

${ }^{169}$ Bittker, supra note 34 at 166, arguing that: "Side by side with taxpayers who can satisfy their charitable impulses by making a contribution of their time (from which they report no imputed income), are others who feel the same charitable impulse, but must discharge their moral obligation by contributing cash or property. This raises a question of equity between these two classes of taxpayers." See also Andrews, "Personal Deductions in an Ideal Income Tax," supra note 34 at 347-48, referring to a doctor who spends one day a week at a clinic without charging for his services and a lawyer whose skills "are not so directly useful to the poor as those of the doctor" who contributes "part of his fees for distribution among the poor or for the purchase of other services to meet their needs", and concluding that: "The charitable contribution deduction operates to treat the lawyer like the doctor, by taxing him only on the amount of personal consumption and accumulation he realizes from the practice of his profession, not on what he could have realized if he had not given part of his fees away." 
make charitable gifts of large capital sums, the income from which is not subsequently subject to tax in their hand, and individuals who must make charitable contributions out of income as it is earned. ${ }^{170}$

With respect to the first argument, that charitable donations should be regarded as involuntary obligations, one may respond that whatever sense of obligation may underlie the motive to make charitable gifts is itself a matter of choice and not involuntary in any legal or practical sense. ${ }^{171}$ In this respect, as several commentators have observed, charitable contributions can be characterized as a form of consumption expenditure much like any other, which is properly subject to tax. ${ }^{172}$ Moreover, while the conception of charitable donations as involuntary obligations may have influenced the original design of the Canadian deduction, which was limited to 10 percent of the taxpayer's income in accordance with "the Mosaic law and the practice of tithing", ${ }^{173}$ subsequent amendments increasing the level of this ceiling to 20 percent, 50 percent and now 75 percent suggest a very different rationale.

With respect to the second argument that charitable donations are properly taxed in the hands of the recipients of these gifts, rather than the donors for whom the money or property is "no longer available", ${ }^{174}$ one can respond that this conception of the income tax misconstrues both its purpose and its proper scope. As opposed to Andrews' view that the income tax is intended simply "to divert economic resources away from personal consumption and accumulation" to government uses, ${ }^{175}$ for example, several tax theorists contend that the income tax is best understood as expressing a social claim to a share of each taxpayer's annual gains from participation in the market economy. ${ }^{176}$ As a result, while Andrews argues that tax burdens should be allocated according to personal welfare as measured either by the aggregate of a taxpayer's personal consumption and accumulation, ${ }^{177}$ or by personal consumption alone (as he argued in a later article), ${ }^{178}$ advocates of the income tax argue that tax burdens should be allocated according to each

\footnotetext{
${ }^{170}$ Bittker, supra note 34 at 166 , arguing that "of two charitably minded persons, one may be able to satisfy his impulse by a transfer of inherited or accumulated property; once he has made his gift, whether in trust or outright, the income from that property is thereafter devoted to the charitable purpose and never again shows up in his tax return. The second person must rely upon contributions out of current earnings to discharge his moral obligation. The deduction helps to equalize their circumstances; its repeal would, in my opinion, create an inequitable disparity between them."

${ }^{171}$ See, e.g., McGregor, supra note 25 at 442, commenting that "[c]haritable contributions ... are not a vital necessity of life and are voluntary"; and Boadway and Kitchen, supra note 156 at 71, contrasting medical expenses, "which are almost always involuntary," with charitable donations, which "are not a vital necessity of life and tend to be made on a voluntary basis.

${ }^{172}$ See, e.g., Rendall, supra note 20 at 152; and Brooks, Financing the Voluntary Sector, supra note 77 at 4.

${ }^{173}$ Watson, supra note 18 at 9, citing comments by then Leader of the Opposition R.B. Bennett.

${ }^{174}$ Goodman, "Correspondence," supra note 166 at 399.

${ }^{175}$ Andrews, "Personal Deductions in an Ideal Income Tax," supra note 34 at 325-26.

${ }^{176}$ For a succinct statement of this position, see Alvin Warren, "Would a Consumption Tax Be Fairer Than an Income Tax?" (1980), 89 Yale L.J. 1081, arguing among other things that this view is more consistent with liberal-egalitarian values than that advanced by Andrews. See also Charles R. O'Kelley, "Rawls, Justice, and the Income Tax" (1981), 16 Georgia L. Rev. 1. As the title of O'Kelley's article suggests, the basis for much of this thinking about the purpose of the income tax is John Rawls, A Theory of Justice, (Cambridge, MA: Harvard University Press, 1971).

${ }_{177}^{177}$ Andrews, "Personal Deductions in an Ideal Income Tax," supra note 34 at 317-31.

${ }^{178}$ William D. Andrews, "A Consumption-Type or Cash Flow Personal Income Tax" (1974), 87 Harv. L. Rev. 1113.
} 
taxpayer's receipts over a specified accounting period, allowing deductions only for the costs of earning this revenue, or for involuntary expenses which reduce the taxpayer's ability to pay. ${ }^{179}$

From this perspective, it follows, the argument that amounts donated by a taxpayer to charities are not the income of the donor ignores that fact that the donor is legally entitled to these amounts before the voluntary choice to make a gift to charity. To the extent that the income tax is based on amounts to which taxpayers are legally entitled, therefore, it is simply incorrect to view donations as the income of the recipient rather than the donor. Indeed, as Bromley himself notes, "taxpayers are giving away their own money"180 If the donation is, in fact, "their own money", it should be taxed in their hands and paid out of after-tax income, not in the hands of the recipient. ${ }^{181}$

As for the third argument that a deduction for charitable contributions is essential to an equitable income tax, one can respond that donors who contribute money out of earned income are not similarly situated to donors to make gifts of services or contribute large capital sums the subsequent income from which belongs to the charitable organization not the donor. With respect to donations of services, time devoted to volunteer work may compete not with time devoted to taxable income-earning activities, but with time devoted to non-taxable leisure. More generally, while it is true that donors of services are not subject to tax on the imputed value of these services, this turns not on an implicit deduction for this imputed value, but on a more basic principle against the taxation of imputed income. ${ }^{182}$ Indeed, to the extent that tax assistance is designed to encourage charitable gifts and subsidize charitable activities, it is arguable that it is inequitable for the income tax recognize donations of cash and property but not gifts of services. $^{183}$

With respect to donations of capital, it is worth noting that these donations may or may not be used by the recipient organization to derive a regular stream of income. Conversely, smaller donations made out of earned income may be added to the recipient's capital account to generate future income. As a result, the nature of the gift to the donor says nothing about its character to the donee. In any event, to the extent that the charitable recipient does use the charitable gift to derive subsequent income, it is clear that this income, unlike the income from which a donor makes annual gifts, is legally that of the charitable organization and no longer that of the donor. Since the donor of the capital gift has parted with his or her entitlement to the income from the capital, while the individual who makes annual donations out of earned income retains the legal right to contribute or not contribute in any year, it is odd to equate the position of

\footnotetext{
${ }^{179}$ See, e.g., Thirsk, supra note 77 at 33 .

${ }^{180}$ Bromley, supra note 113 at 7.

${ }^{181}$ This result is, of couse, subject to any reduction in the donor's tax that might be introduced for purposes extrinsic to the task of defining income. See the discussion at infra, Part III, Sections 2, 3, and 4.

${ }^{182}$ See the discussion at supra, notes 33-36 and accompanying text. See also Brooks, Financing the Voluntary Sector, supra note 77 at 5-6.

${ }^{183}$ See supra, Part II, Section 2.
} 
the former with that of the latter. ${ }^{184}$ Here too, therefore, tax equity does not require a deduction for charitable contributions.

\section{Rewarding Generosity}

If tax equity does not mandate a deduction for charitable contributions, tax recognition of charitable gifts must be justified, if at all, on the basis of some social or economic policy extrinsic to the equitable definition of taxable income. One such policy might be to reward generosity as a form of virtuous behaviour. Among other arguments for a charitable deduction, for example, Bittker suggests that "something can be said for rewarding activities that in a certain sense are selfless, even if the reward serves no incentive function." " 185 Similarly, Richard Goode has referred to the charitable deduction in the U.S. as a "reward" for charitable giving. ${ }^{186}$

Although the goal of rewarding charitable donations might justify some method of recognizing the value of these donations in computing the donor's income tax, it is doubtful whether this recognition would take the form of a deduction, the value of which depends more on the donor's income than the donor's relative generosity. On the contrary, as Paul McDaniel has argued:

... if there is to be a reward for charitable giving, the incidence and amount of the reward should bear some rational relationship to the act of charitable giving. The reward should be the same for persons who make a similar sacrifice, however measured. ${ }^{18}$

Indeed, since low income people who give to charities tend to give a larger portion of their income than high income taxpayers, ${ }^{188}$ this rationale suggests that a deduction, the value of which increases as the donor's income rises, has the reward structure backwards.

\footnotetext{
${ }^{184} \mathrm{~A}$ possible exception to this conclusion might exist where the donor enters into a legally binding commitment to donate a specific amount every year for a certain number of years. This view, in fact, appears to underlie the U.K. "covenant" system, whereby donors are not taxable on amounts paid to a charity pursuant to a legal covenant which fulfils the requirements of the tax statute. On the other hand, it might be argued that donors who enter into these arrangements are still giving away "their own money" (albeit prior to its actual receipt) which should therefore be taxed in their hands. For an explanation of this system, see McLean, Kluger and Henrey Interphil, Charitable Contributions in the OECD, supra note 8 at $155-61$.

${ }^{185}$ Bittker, supra note 34 at 166.

${ }^{186}$ Goode, supra note 22 at 165.

${ }^{187}$ McDaniel, supra note 36 at 394.

${ }^{188}$ See Bird and Bucovetsky, supra note 19 at 18 (Table 18), reporting for the 1972 taxation year that for taxpayers claiming charitable contributions, the percentage of average income among different income groups was 7.8 percent for donors with incomes less than $\$ 5,000,4.1$ percent for donors with incomes of $\$ 5,000$ to $\$ 10,000,2.9$ percent for donors with incomes of $\$ 10,000$ to $\$ 20,000,2.4$ percent for donors with incomes of $\$ 20,000$ to $\$ 50,000,2.4$ percent for donors with incomes of $\$ 50,000$ to $\$ 100,000$, and 3.6 percent for donors with incomes exceeding $\$ 100,000$. More recent figures from the 1990 taxation year, demonstrate a similar U-shaped ratio of charitable donations to income level of donors, falling from 4.1 percent for donors with taxable incomes less than $\$ 10,000$ to 2.1 percent for donors with taxable incomes of $\$ 10,000$ to $\$ 30,000,1.4$ percent for donors with taxable incomes of $\$ 30,000$ to $\$ 50,000,1.3$ percent for donors with taxable incomes of $\$ 50,000$ to $\$ 100,000,1.7$ percent for donors with taxable incomes of
} 
As opposed to a deduction, therefore, the reward rationale might suggest a credit that diminishes as the donor's income increases, on the basis that the sacrifice associated with a dollar contributed to charity by a low-income taxpayer is greater than the sacrifice of a dollar gift by a high-income taxpayer. ${ }^{189}$ Neil Brooks, for example, suggests that a tax credit for charitable contributions "could be set at 30 per cent for those with incomes over $\$ 35,000$; 40 per cent for those with incomes from $\$ 25,000$ to $\$ 35,000$, and so on, down to those with incomes under $\$ 10,000$, where the credit might be set at 100 per cent.",190

Alternatively, to the extent that the policy objective is to reward individuals based on the proportion of their income contributed to charities, a credit might apply at an increased rate based on the percentage of the donor's income contributed in each year. ${ }^{191}$ On this basis, for example, McDaniel proposed a matching grant for charitable donations rising from 5 percent of aggregate donations from donors contributing less than 2 percent of their incomes to charities to 50 percent of aggregate donations from donors contributing more than 10 percent of their incomes to charities. ${ }^{192}$ Similarly, some commentators have proposed an income-related floor, as opposed to a ceiling, below which charitable contributions would not be recognized for tax purposes. ${ }^{193}$ In 1969, for example, the U.S. Treasury Department proposed that the charitable deduction in the U.S. Internal Revenue Code be available only for contributions exceeding 3 percent of the donor's income. ${ }^{194}$ Similarly, the Carter Commission considered, but rejected, a floor set at 1 percent of the donor's income. ${ }^{195}$ In addition to targeting the "reward" to the most generous contributors, such a floor might also be expected to reduce administrative costs associated with tax assistance for charitable giving. ${ }^{196}$

On the other hand, to the extent that low-income individuals who contribute to charities are able to finance these gifts from accumulated or inherited wealth, one might wonder whether the ratio between donations and income is a satisfactory measure of the donor's personal "sacrifice". If the goal is truly to reward individual generosity, therefore, one might imagine a credit based on the ratio between donations and a combined measure of income and wealth. Such a measure, of course, would be difficult to define and even more difficult to administer.

$\$ 100,000$ to $\$ 250,000$, and 1.9 percent for donors with taxable incomes exceeding $\$ 250,000$. Calculated from figures in Revenue Canada, Taxation Statistics on Individuals: 1990 Tax Year, (Ottawa: Minister of Supply and Services, 1992).

${ }^{189}$ See, e.g., McDaniel, supra note 36 at 383 , commenting that it is "less burdensome for a person with $\$ 200,000$ to give 10 per cent of his income to charity than it is for a $\$ 12,000$ a year wage earner to give the corresponding 10 percent."

${ }^{190}$ Brooks, Financing the Voluntary Sector, supra note 77 at 24.

${ }^{191}$ See, e.g., McDaniel, supra note 36 at 394, arguing that the reward rationale "appears to call for a system which increases the reward as the individual sacrifices a greater proportion of his income to charity."

${ }^{192} \mathrm{Ibid}$. at 397.

${ }^{193}$ See, e.g., Bittker, supra note 34 at 169, suggesting that the floor should exclude the least generous 10 or 20 percent of donors; and Goode, supra note 22 at 165, commenting that such a measure would "focus the reward or incentive more sharply by withdrawing the deduction from persons whose contributions are small relative to income while continuing it for heavier contributions."

${ }^{194}$ See the discussion of this proposal in McDaniel, supra note 36 at 387-88.

${ }^{195}$ Carter Commission, supra note 48 at 224.

${ }^{196}$ See, e.g., Rendall, supra note 20 at 159; and Goode, supra note 22 at 165. 
More generally, one might wonder why the tax system should be designed to reward persons for their generosity. Although generosity is undoubtedly worthy of praise, it is not clear that it merits monetary rewards. On the contrary, as critics from different perspectives have observed, to reward generosity through monetary means contradicts the spirit underlying the virtue of generosity, "corrupt[ing] the essential dignity and altruism of a simple gift," ${ }^{197}$ and "accentuat[ing] the purely selfish goal of reducing one's own tax burden."

\section{Encouraging Donations}

Another reason to allow taxpayers to claim a charitable deduction or credit is to encourage individuals to make donations to charitable organizations. As economic analysis suggests, a deduction or credit for charitable gifts increases the donor's after-tax income from which gifts may be made (the income effect) and decreases the after-tax cost or price of charitable gifts to the donor (the price or substitution effect). ${ }^{199}$ To the extent that charitable giving is what economists refer to as a "normal good", a decrease in its price will increase the quantity demanded and thus the aggregate level of charitable donations. The higher the rate of the deduction or credit, moreover, the lower the after-tax cost of charitable giving and the greater the encouragement to these kinds of gifts.

The extent to which donors increase the quantity of charitable giving in response to a decrease in its after-tax cost is defined as the "price elasticity" of giving. ${ }^{200}$ A negative price elasticity, which is characteristic of a normal good, suggests that donations will increase in response to a decrease in their price. A low price elasticity indicates a slight increase in charitable giving in response to a decrease in its after-tax cost. A high price elasticity suggests that the quantity of charitable donations is highly responsive to changes in the after-tax cost of these gifts. A price elasticity of negative one indicates a corresponding increase in charitable giving in response to a given reduction in its after-tax cost.

Since reductions in the after-tax cost of charitable gifts are financed by foregone tax revenues, the price elasticity of charitable giving measures the cost-effectiveness of the tax incentive (whether a deduction or a credit) as a means of funding charitable organizations. While a price elasticity less then negative one indicates that the cost of the tax incentive in terms of foregone revenues exceeds the resulting increase in charitable donations, a price elasticity greater than negative one implies that the increase in charitable donations attributable to the tax incentive exceeds the resulting reduction in tax revenues.

\footnotetext{
${ }^{197}$ Bromley, supra note 113 at 12.

${ }^{198}$ Brooks, Financing the Voluntary Sector, supra note 77 at 13.

${ }^{199}$ See Taussig, supra note 85 at 3, adding that: "Only the price or substitution effect ... can be properly regarded as the result of ... the ... policy variable, since the income effect ... is incidental and could be achieved equally well by a cut in tax rates, an increase in personal exemptions, and by similar alternative devices."

${ }^{200}$ For a useful introduction to this concept, see Scharf, Cherniavsky and Hogg, supra note 46 at 8-9.
} 
A voluminous literature has developed over the past thirty years as economists have attempted to obtain reliable estimates of the price elasticity of charitable giving. ${ }^{201}$ Although the earliest studies reported relatively low price elasticities of charitable giving, ${ }^{202}$ suggesting that tax incentives are a relatively inefficient means of funding charitable organizations, ${ }^{203}$ subsequent studies have reported price elasticities greater than negative one, ${ }^{204}$ suggesting that tax incentives may be a cost-effective method of funding charitable organizations. ${ }^{205}$ More recent studies using different methodologies have reported much lower estimates of price elasticities, ${ }^{206}$ again calling into question the efficiency of tax incentives as a method of funding the charitable sector. ${ }^{207}$

With respect to the relationship between the price elasticity of charitable giving and other variables, early studies concluded that elasticity increases as income increases, ${ }^{208}$ suggesting that a deduction is a more efficient method of encouraging charitable donations than a flat-rate credit. ${ }^{209}$ Subsequent studies indicate that low- and middle-income taxpayers may be more responsive to the after-tax cost of charitable giving than previously thought, ${ }^{210}$ suggesting that a flat-rate credit may be inefficient. Most studies, however, suggest that the price elasticity of charitable giving is much lower for donations to religious organizations than other charities, ${ }^{211}$ suggesting that tax incentives of any kind are a inefficient way to fund religious organizations. Finally, although empirical studies do not appear to have confirmed the result, one might expect that donations of capital property are more responsive to the price of giving than contributions out of annual income which are more likely to reflect a sense of personal obligation. ${ }^{212}$

\footnotetext{
${ }^{201}$ For summaries of this literature, see J.A. Johnson, "The Determinants of Charitable Giving with Special Emphasis on the Income Deduction under the Income Tax - A Survey of the Empirical Literature" (1981), 3 Can. Taxation 258; Clotfelter, Federal Tax Policy and Charitable Giving, supra note 97 at 16-99; and Scharf, Cherniavsky and Hogg, supra note 46 at 11-17.

${ }^{202}$ See, e.g., Taussig, supra note 85; Robert A. Schwartz, "Personal Philanthropic Contributions" (1970), $78 \mathrm{~J}$. Pol. Econ. 1264; and Hood, Martin and Osberg, supra note 89.

${ }^{203}$ See, e.g, Rendall, supra note 20 at 158-59; Wolkoff, supra note 77 at 291-93; and Brooks, Financing the Voluntary Sector, supra note 77 at 18-21.

${ }^{204}$ See, e.g., Martin Feldstein, "The Income Tax and Charitable Contributions: Part I - Aggregate and Distributional Effects" (1975), 28 Nat. Tax J. 81; Charles T. Clotfelter and C. Eugene Steuerle, "Charitable Contributions," in Henry J. Aaron and Joseph A. Pechman, How Taxes Affect Economic Behaavior, (Washington, D.C.: Brookings Institution, 1980) 403; Kitchen and Dalton, supra note 85; and Harry Kitchen, "Determinants of Charitable Donations in Canada: A Comparison Over Time" (1992), 24 Applied Econ. 709.

${ }^{205}$ See, e.g., Scharf, Cherniavsky and Hogg, supra note 46 at 9 and 14.

${ }^{206}$ See, e.g., William C. Randolph, "Dynamic Income, Progressive Taxes, and the Timing of Charitable Contributions" (1995), 103 J. Pol. Econ. 709; and Kevin Stanton Barrett, Anya M. McGuirk, and Richard Steinberg, "Further Evidence on the Dynamic Impact of Taxes on Charitable Giving" (1997), 50 Nat. Tax J. 321 .

${ }^{207}$ See, e.g., ibid. at 332.

${ }^{208}$ See, e.g., Aaron, "Federal Encouragement of Private Giving" supra note 97.

${ }^{209}$ See, e.g., Glenday, Gupta and Pawlak, supra note 98 and accompanying text.

${ }^{210}$ See, e.g, Michael J. Boskin and Martin Feldstein, "Effects of Charitable Deductions on Contributions by Low Income and Middle Income Households: Evidence from the National Survey of Philanthropy" (1978), 59 Rev. Econ. \& Stats. 351; and Yong S. Choe and Jinook Jeong, "Charitable Contributions by Low- and Middle-Income Taxpayers: Further Evidence with a New Method" (1993), 66 Nat. Tax J. 33.

${ }^{211}$ See, e.g, Feldstein, supra note 85; and Kitchen and Dalton, supra note 85.

${ }^{212}$ For an argument to this effect, though not phrased in economic discourse, see Bromley, supra note 113 at 14-16.
} 
Indeed, the assumption that donations out of capital are more price elastic than donations out of income appears to explain recent amendments to the Income Tax Act lowering the rate of capital gains tax on gifts of publicly-traded securities.

To the extent that tax provisions recognizing charitable gifts are designed to encourage individuals to make charitable donations, economic analysis suggests that the most cost-effective method of so doing is to provide the greatest incentive to those categories of donors and/or donations for which the price elasticity of giving is greatest. While these efficiency considerations may suggest larger incentives for gifts of capital property and smaller incentives for gifts to religious organizations, they challenge the assumption that a deduction is more efficient than a credit in encouraging charitable donations.

Efficiency, of course, is only one goal of tax policy and must be weighed against other important values such as equity. ${ }^{213}$ Although it might be more cost-effective to reduce or eliminate tax incentives for gifts to religious organizations, such an approach might be considered inequitable. Likewise, while lower capital gains taxes on gifts of appreciated property may be a cost-effective way to encourage gifts of capital property, this incentive is arguably inequitable and arbitrary, providing the greatest benefit to taxpayers in the highest tax brackets with property which happens to have appreciated most in value. ${ }^{214}$

Moreover, the use of tax incentives to encourage donations to charitable organizations raises deeper questions as to the kinds of organizations donations to which should be encouraged, and why these donations should be encouraged in the first place. As the final section of this paper suggests, the ultimate rationale and appropriate design of a tax incentive for charitable donations depends on the answers to these questions.

\section{Promoting Pluralism}

Among economists, the charitable sector is generally regarded as a provider of quasi-public goods and services -- the key characteristics of which are nonrivalness, meaning that enjoyment by one person does not preclude enjoyment by another, and nonexcludability, meaning that it is difficult or impossible to exclude a person from enjoying the benefit even is he or she refuses to pay for it. $^{215}$ To the extent that a good or service is relatively nonrival and/or nonexcludable, economic analysis suggests that private markets will either oversupply the good or service (in the case of nonrival but excludable goods and services) or undersupply the good or service (in the case of nonexcludable goods or services). In either case, the resolution of these "market imperfections" is the main economic justification for the existence of a

\footnotetext{
${ }^{213}$ See, e.g., Martin Feldstein, “A Contribution to the Theory of Tax Expenditures: The Case of Charitable Giving" in Henry J. Aaron and Michael J. Boskin, eds., The Economics of Taxation, (Washington, D.C.: Brookings Institution, 1980) 99 at 121.

${ }^{214}$ See supra, text accompanying note 69.

${ }^{215}$ See, e.g., Scharf, Cherniavsky and Hogg, supra note 46 at 4-5.
} 
public sector which provides these public goods and services directly, distributing their costs among individual beneficiaries through taxes and other levies. ${ }^{216}$

In addition to the public sector, the charitable sector represents another response to the existence of market imperfections, providing goods and services such as culture, education, health, and welfare, the benefits of which tend to be relatively nonrival and/or nonexcludable. ${ }^{217}$ Indeed, since charitable organizations enable individuals to select public goods and services according to their own values and preferences, this sector may have distinct advantages over the public sector in providing a mix of such goods and services more compatible with the demands of a diverse society. ${ }^{218}$ Moreover, to the extent that the charitable sector is more innovative and service-oriented than the traditional public sector, it may provide a more efficient vehicle for the delivery of certain public goods and services. ${ }^{219}$ As well, by relieving the public sector from sole responsibility for providing public goods and services, the charitable sector lessens the fiscal burdens of the public sector, ${ }^{220}$ making it better able to perform the important redistributive, allocative and stabilization functions that only it can effectively fulfill. ${ }^{221}$ From this perspective, fiscal subsidies to the charitable sector may be justified on the grounds that they increase the supply of public goods and services provided by this sector to levels reflecting their positive public

\footnotetext{
${ }^{216}$ While market imperfections provide an economic justification for the existence of a public sector, the existence of the states may also be justified on non-economic terms, for examplel to ensure that economic resources are distributed fairly. The following analysis should not be read to suggest that this distributive role should nor can be adequately fulfilled by charitable organizations. On the contrary, as Will Kymlicka explains in his contribution to this volume, according to a liberal conception of justice these distributive considerations are properly understood as matters of justice, not charity. See Will Kymlicka, "Philosophical and Ethical Traditions and Altruism," in Jim Phillips and Bruce Chapman, eds., Charities: Between State and Market, (Kingston: McGill-Queen's, 1999) xxx at xxx-xxx.

${ }^{217}$ This sector is often described as the "voluntary sector" to distinguish its method of finance from the public sector which relies upon compulsory taxes and levies. See, e.g., Burton A. Weisbrod, "Toward a Theory of the Voluntary Nonprofit Sector in a Three-Sector Economy," in Susan Rose Ackerman, ed., The Economics of Non-Profit Institutions: Studies in Structure and Policy, (New York: Oxford University Press, 1986) 21.

${ }^{218}$ See, e.g., Lester M. Salamon, "Partners in Public Service: The Scope and Theory of Government-Nonprofit Relations," in Walter Powell, ed., The Non-profit Sector: A Research Handbook (New Haven, Conn.: Yale University Press, 1987) 99.

${ }^{219}$ See, e.g., Scharf, Cherniavsky and Hogg, supra note 46 at 5, suggesting that "voluntary organizations foster a do-it-yourself culture, which can improve accountability, encourage technological innovation, and promote efficiency in the use of resources, which may be more desirable if government provision is encumbered with a lot of bureaucracy." See also Richard Domingue, The Charity "Industry" and its Tax Treatment, (Ottawa: Minister of Supply and Services, 1995) at 3, arguing that: "At a time when attempts are being made to reinvent government, it should perhaps be recognized that social services could be provided much more efficiently by charitable organizations. It could be that communities and local agencies are in a better position to assess and meet these needs economically than government employees working in a capital city far removed from the people they serve."

${ }^{220}$ See, e.g., McGregor, supra note 25 at 442 , noting that charitable contributions "relieve the government of some of its responsibilities, and make possible some activities, such as those of a cultural nature, which the government might not feel impelled, or be able, to afford to carry on."

${ }^{221}$ For an introduction to these functions of the public sector, see Richard Musgrave, Peggy Musgrave, and Richard Bird, Public Finance in Theory and Practice, (Toronto: McGraw Hill, 1987).
} 
benefits or "externalities", and finance alternative methods of delivering public goods and services to those employed by the traditional public sector. ${ }^{222}$

Having concluded that fiscal subsidies to the charitable sector are justified, however, it is not obvious why these subsidies should be provided indirectly to charitable donors in the form of credits or deductions rather than directly to charitable organizations in the form of sustaining grants or matching grants. Indeed, in his contribution to this volume, Neil Brooks offers a number of reasons why direct sustaining grants are generally preferable to direct matching grants and direct matching grants generally preferable to indirect tax expenditures as methods of subsidizing the charitable sector, emphasizing that sustaining grants allocate scarce public funds more rationally than matching grants or tax expenditures and are most consistent with "the basic criteria that are normally applied to government funding, such as accountability, controllability and transparency.,223

While these arguments support a significant role for direct government grants in financing the voluntary sector, ${ }^{224}$ they do not rule out direct matching grants or indirect tax expenditures as additional sources of fiscal support. Indeed, to the extent that these methods of financing allow individuals to select the charitable organizations to which they wish to direct public support without having to obtain the agreement of a political majority, they are preferable to direct sustaining grants in promoting the very diversity and innovation that underlies the charitable sector's unique advantages to the traditional public sector and less susceptible to political manipulation by a governing party or coalition. ${ }^{225}$ Moreover, although it might be argued that direct matching grants are as consistent with this objective as indirect tax expenditures, ${ }^{226}$ the latter are more likely than the former to withstand the kinds of political controls that

\footnotetext{
${ }^{222}$ See Harold M. Hochman and James D. Rodgers, "The Optimal Tax Treatment of Charitable Contributions" (1977), 30 Nat. Tax. J. 1 at 2-3. See also Gergen, supra note 165 at 1396-1414.

${ }^{223}$ Neil Brooks, "The Role and Financing of the Voluntary Sector in a Modern Welfare State" in Phillips and Chapman, supra note 216, xxx at $\mathrm{xxx}-\mathrm{xxx}$.

${ }_{224}^{24}$ Indeed, a recent study indicates that direct government funding constitutes a much larger (and increasing) share of the revenues of charitable organizations as a whole than donations. See Kathleen M. Day and Rose Ann Devlin, The Canadian Nonprofit Sector, Paper No. CPRN 02, (Ottawa: Canadian Policy Research Networks, 1997) at 15-16, reporting that the percentage of charitable organization revenues derived from government funding increased from 42.8 percent in 1989 to 11.3 percent in 1994 while the percentage of revenues from donations decreased from 21.8 percent in 1989 to 11.3 percent in 1994.

${ }^{225} \mathrm{In}$ this respect, it is instructive to consider recent contoversy in Ontario regarding control of the Trillium Foundation, which distributes roughly $\$ 100$ million in funds raised through provincially-run lotteries and casinos. Although Brooks himself refers to the Trillium Foundation in his paper in this volume, he does not consider the implications of the recent contoversy for his argument that direct sustaining grants are generally preferable to direct matching grants or indirect tax expenditures. See Brooks, "The Role and Financing of the Voluntary Sector in a Modern Welfare State" supra note 223 at xxx.

${ }^{226}$ See, e.g., ibid. at $\mathrm{xxx}-\mathrm{xxx}$, arguing that a system of direct matching grants would be more equitable than the current credit, more visible than a credit or deduction, administratively simpler than a credit or deduction, and more easily policed than a credit or deduction. On the other hand, as Brooks has himself acknowledged, to the extent that it is considered desirable to vary the rate of the fiscal subsidy with the amount contributed by individual donors, an indirect tax expenditure is preferable to a system of direct matching grants. I return to this point at infra, notes 243-46 and accompanying text. See Brooks, Financing the Voluntary Sector, supra note 77 at 32.
} 
would undermine their effectiveness in promoting pluralism. ${ }^{227}$ As a result, even if tax incentives were a less cost-effective method of subsidizing charitable organizations than direct government grants, ${ }^{228}$ it is arguable that the former are preferable to the latter on broader policy grounds. As Harold Hochman and James Rodgers have written: "Public policy involves much more than whether an additional dollar of subsidies can generate more than a dollar of charity.",229

Turning to the design of these tax incentives, the rationale of subsidizing charitable organizations that provide quasi-public goods and services suggest a structure of deductions or credits corresponding to the degree of "publicness" of the particular good or service provided by the charitable organization to which the donation is made. ${ }^{230}$ Thus, as one Canadian commentator has suggested:

... it would be desirable to disaggregate within an expenditure category and confer different rates of credit on items that contribute different amounts of social benefit. Not all charitable activities, for example, may yield the same degree of social value, in which case a policy of differentiated tax credits is called for. ${ }^{231}$

Indeed, by exempting capital gains tax on gifts of cultural property, ${ }^{232}$ it might be argued that the Income Tax Act reflects an implicit judgment that gifts of this type provide greater social benefits than other charitable gifts. A similar distinction may underlie the absence of income-related ceilings on gifts to the Crown, gifts of cultural property and gifts of ecologically sensitive land. ${ }^{233}$

With respect to the choice between a deduction and a credit, some have favoured a deduction on the grounds that it provides a larger tax subsidy to charitable organizations favoured by high-income donors (hospitals, higher education, and cultural institutions), which are assumed to be "richer contributors to the social, cultural, and intellectual mosaic" than the charitable organizations most favoured by lowerincome donors (religious organizations and social welfare). ${ }^{234}$ Faye Woodman, for example, suggests that a deduction "gives more support to charities that do what government would otherwise have to do" than a

\footnotetext{
${ }^{227}$ See, e.g., Bittker, supra note 34 at 147-52, concluding that "I have very little confidence that a system of matching grants could be administered without administrative and congressional investigations, loyalty oaths, informal or implicit warnings against heterodoxy, and the other trappings of governmental support than the tax deduction has, so far, been able to escape"; and Goode, supra note 22 at 163, considering it "unlikely" that a system of direct matching grants "would be as free of undesirable controls or would serve the values of pluralism as well."

${ }^{228}$ See supra, text accompanying notes 201-07.

${ }^{229}$ Hochman and Rodgers, supra note 222 at 11.

${ }^{230}$ See, e.g., ibid. at 14 , arguing that "[ $[$ t]he proper level of the tax credit depends ... on the 'external' content of the benefits that the charity-financed activities confer; it depends, in other words, on the relationship between the marginal evaluations of the primary sharing group, namely voluntary donors, and the community-at-large." See also Scharf, Cherniavsky and Hogg, supra note 46 at 9, suggesting that "we should try to encourage donations to charities that provide goods or services to a large number of consumers."

${ }^{231}$ Thirsk, supra note 77 at $41-42$.

${ }^{232}$ See supra notes $71-73$ and accompanying text.

${ }^{233}$ See supra notes 131-38 and accompanying text.

${ }^{234}$ Woodman, supra note 99 at 575.
} 
credit. ${ }^{235}$ To the extent that Canada's two-tier credit operates much like a deduction, the same argument might be made in its favour.

To others, however, it is unlikely that the charitable organizations generally favoured by highincome donors generate greater positive externalities than those more favoured by low-income taxpayers. ${ }^{236}$ On the contrary, as a recent study concludes:

Available evidence ... seems to suggest that the activities of the nonprofit organizations and charities typically supported by the rich do not produce higher valued externalities than do those supported by lower income earners. In fact, the converse may be true: universities and cultural organizations are charities that may be viewed as more "local" than churches and religious organizations. Thus larger giving by high income earners should be discouraged on efficiency grounds, while smaller gifts by low income earners should be encouraged. ${ }^{237}$

Moreover, although lower-income donors tend to devote a larger share of their donations to religious organizations, U.S. studies suggest that 20 percent of these funds are devoted to non-sacramental purposes such as social welfare. ${ }^{238}$ In a pluralistic society, moreover, who is to say that the public benefits associated with religious activities are any less than those associated with higher education? $?^{239}$

Indeed, to the extent that pluralism itself is regarded as a public good, it is arguable that a tax incentive for charitable contributions should not discriminate among different activities or organizations, except to deny charitable status to organizations advocating values contrary to those of a free and democratic society. ${ }^{240}$ In any event, where a decision is made to discriminate in favour of certain kinds of

${ }^{235} \mathrm{Ibid}$. at 574 .

${ }^{236}$ See, e.g., Hochman and Rodgers, supra note 222 at 13.

${ }^{237}$ Scharf, Cherniavsky and Hogg, supra note 46 at 28.

${ }^{238}$ Commission on Private Philanthropy and Public Needs (Filer Commission), Giving in America: Toward a Stronger Voluntary Sector (Washington, D.C.: The Commission, 1975) at 57.

${ }^{239}$ See, e.g., Bromley, supra note 113 at 14, arguing that: "Religious activities are justifiably 'charitable' on the basis that they are beneficial to the community as a whole because they contribute to bettering the conduct and character of citizens." For a contrary view of religious organizations, see Wolkoff, supra note 77 at 288, arguing that most religious gifts "help maintain the donors congregations" and are "directed at satisfying the needs of the donor, not at satisfying the needs of society at large."

${ }^{240}$ Although I have not examined the issue in detail, this argument suggests a much wider definition of "charity" than that currently accepted by the courts and Revenue Canada -- a definition which, at the very least, seems incompatible with the political purposes doctrine. On the legal definition of charity, see Jim Phillips, "The Federal Court of Appeal and the Legal Meaning of Charity: A Review and Critique," in Phillips and Chapman, supra note 216, xxx; Mayo Moran, "Rethinking Public Benefit: The Definition of Charity in the Era of the Charter," in Phillips and Chapman, supra note 216, xxx; and Jim Phillips, "Religion, Charity, and the Charter of Rights," in Phillips and Chapman, supra note 216, xxx. On the political purposes doctrine, see Abraham Drassinower, "The Doctrine of Political Purposes in the Law of Charities: A Conceptual Analysis," in Phillips and Chapman, supra note 216, xxx; and Bruce Chapman, "Rational Voluntarism and the Charitable Sector," in Phillips and Chapman, supra note 216, xxx. On the administrative processes surrounding registration and deregistration as a charitable organization under the Income Tax Act, see Lorne Sossin, "Regulating Virtue: A Purposive Approach to the Administration of Charities in Canada," in Phillips and Chapman, supra note 216, xxx. For an excellent example of a reasonable limit on acceptable pluralism in a free and democratic society, see the decision in Bob Jones University v. United States, 461 U.S. 574 (1983), in which the U.S. Supreme Court denied charitable status to a nonprofit private school following a racially discriminatory admissions policy. For a more thorough examination of this issue, see Mayo Moran, "Rethinking Public Benefit: The Definition of Charity in the Era of the Charter," in Phillips and Chapman, supra note 216, xxx at xxx-xxx. 
charitable activities (e.g., higher education) and against others (e.g., religious organizations), this decision should be transparent, not concealed in the form of a deduction or the current two-tier credit. ${ }^{241}$ As Neil Brooks has written: "If certain activities are to be favoured over others, that choice should be clearly reflected on the face of the instrument chosen.",242

Finally, although a flat-rate credit might be regarded as more compatible with the goal of promoting pluralism than a deduction or the current two-tier credit, it is arguable that such a credit fails to take pluralism as seriously as it might. On the one hand, donors with little or no taxable income obtain no benefit from the nonrefundable credit. ${ }^{243}$ On the other hand, high-income donors who are able to contribute more to charities can obtain substantial tax assistance up to whichever income-related ceiling may apply. Although pluralistic in name, therefore, the distribution of charitable donations among income groups may foster a form of "philanthropic paternalism" in which the mix of goods and services provided by the charitable sector is shaped more by an affluent minority than the community as a whole.

From this perspective, one might wonder whether recent increases in the income-related ceiling for allowable credits from 20 percent to 50 percent and now 75 percent are fully compatible with the goal of promoting pluralism. ${ }^{244}$ In contrast, a more meaningful kind of pluralism might be fostered by restructuring the charitable credit along the lines of the political contributions tax credit, which equals three-quarters of the first $\$ 100$ contributed, half of the next $\$ 450$, and one-third of the next $\$ 600$, for a maximum credit of $\$ 500$ on a contribution of $\$ 1,150 .{ }^{245}$ Indeed, a recent Canadian study has considered this possibility, suggesting that "[a]ll gifts, whether to charities or political parties, should in principle be treated on the same basis." 246

\section{Conclusion}

The design of any income tax provisions taking charitable gifts into account in computing a donor's tax liability should reflect the underlying purpose of the provisions, which should themselves be rationally related to the purposes of an income tax. This paper has argued that a deduction for charitable contributions cannot be justified as a necessary provision to define income nor as a means of rewarding generosity, encouraging donations or promoting pluralism. To the extent that Canada's current two-tier

\footnotetext{
${ }^{241}$ See, e.g., Wolkoff, supra note 77 at 291, concluding that "if some institutions are to be favored over others, the decision should be made democratically".

${ }^{242}$ Brooks, Financing the Voluntary Sector, supra note 77 at 26.

${ }^{243}$ See McDaniel, supra note 36 at 391, suggesting that society would be "greatly enhanced" by extending this pluralism to 100 percent of contributors. See also See Brooks, Financing the Voluntary Sector, supra note 77 at 23-24, arguing for a refundable tax credit.

${ }^{244}$ For a contrary view, see ibid. at 24 , emphasizing that "if the pluralism argument is to be taken seriously, the maximum tax credit available to each taxpayer should be limited."

${ }^{245}$ See subsection 127(3) of the Act.

${ }^{246}$ Scharf, Cherniavsky and Hogg, supra note 46 at 35 , arguing that "from an equity, efficiency, and simplicity point of view, the difference between the tax treatment of political donations and the tax treatment of charities could be viewed as undesirable."
} 
credit is little more than "a deduction masquerading as a credit," may be directed at this approach as well.

Having concluded that tax equity does not mandate a deduction for charitable contributions, this paper considered three alternative reasons for recognizing charitable gifts in computing a donor's tax: rewarding generosity, encouraging donations, and promoting pluralism. While each of these goals suggest various characteristics for the design of specific tax provisions, a combination of the second and third provide the best rationale for a tax incentive for charitable giving.

Taking seriously the goal of promoting pluralism, finally, this paper has argued that a refundable credit with a declining rate based on the amount claimed in each year would be preferable to a deduction, to the existing two-tier credit, or to a nonrefundable flat-rate credit. From this perspective, recent amendments that have increased the annual ceiling on creditable gifts and decreased the rate of capital gains tax on gifts of appreciated property, though consistent with the goal of encouraging donations, are difficult to justify.

\footnotetext{
${ }^{247}$ Bromley, supra note 113 at 5.
} 